Article

\title{
Efficacy Assessment of an Uncharged Reactivator of NOP-Inhibited Acetylcholinesterase Based on Tetrahydroacridine Pyridine-Aldoxime Hybrid in Mouse Compared to Pralidoxime
}

\author{
André-Guilhem Calas ${ }^{1,2, *}$, Anne-Sophie Hanak ${ }^{1,2}$, Nina Jaffré ${ }^{1,2}$, Aurélie Nervo ${ }^{1,2}$, José Dias ${ }^{1}$, \\ Catherine Rousseau ${ }^{1,2}$, Charlotte Courageux ${ }^{1}$, Xavier Brazzolotto ${ }^{1}{ }^{\mathbb{D}}$, Pascal Villa ${ }^{3,4}{ }^{\mathbb{D}}$, \\ Adeline Obrecht ${ }^{3,4}{ }^{\text {, Jean-François Goossens }}{ }^{5}$, Christophe Landry ${ }^{6}$, Johan Hachani ${ }^{6}$, \\ Fabien Gosselet ${ }^{6}{ }^{\circledR}$, Marie-Pierre Dehouck ${ }^{6}$, Jagadeesh Yerri ${ }^{7}$, Maria Kliachyna ${ }^{7}$, Rachid Baati ${ }^{7}$ \\ and Florian Nachon ${ }^{1}$ (D) \\ 1 Département de Toxicologie et Risques Chimiques, Institut de Recherche Biomédicale des Armées, \\ F-91220 Brétigny-sur-Orge, France; anne-sophie.hanak@def.gouv.fr (A.-S.H.); nina.jaffre@def.gouv.fr (N.J.); \\ aurelie.nervo@def.gouv.fr (A.N.); jose.dias@def.gouv.fr (J.D.); catherine.delage@def.gouv.fr (C.R.); \\ charlotte.courageux@def.gouv.fr (C.C.); xavier.brazzolotto@def.gouv.fr (X.B.); \\ florian.nachon@def.gouv.fr (F.N.) \\ 2 COGNition and ACtion Group, UMR 8257, CNRS-MD-UPV, Centre universitaire des Saints-Pères, \\ F-75006 Paris, France \\ 3 CNRS, Université de Strasbourg, PCBIS Plate-forme de Chimie Biologique Intégrative de Strasbourg UMS \\ 3286, F-67412 Illkirch, France; pvilla@unistra.fr (P.V.); aobrecht@unistra.fr (A.O.) \\ 4 Labex MEDALIS, F-67000 Strasbourg, France \\ 5 Université de Lille, ULR-7365-GRITA Groupe de Recherche sur les Formes Injectables et Technologies \\ Associées, F-59000, Lille, France; jean-francois.goossens@univ-lille2.fr \\ 6 Université d'Artois (UArtois), UR 2465, LBHE Laboratoire de la Barrière Hémato-Encéphalique, \\ F-62307 Lens, France; christophe.landry@univ-artois.fr (C.L.); johan.hachani@univ-artois.fr (J.H.); \\ fabien.gosselet@univ-artois.fr (F.G.); mpierre.dehouck@univ-artois.fr (M.-P.D.) \\ 7 UMR CNRS 7515, ICPEES Institut de Chimie et Procédés pour l'Énergie, l'Environnement et la Santé, \\ F-67087 Strasbourg, France; jagadeesh.yerri@gmail.com (J.Y.); kliachyna.maria@gmail.com (M.K.); \\ rachid.baati@unistra.fr (R.B.) \\ * Correspondence: guilhem.calas@def.gouv.fr; Tel.: +33-1-78-65-13-95
}

Received: 7 May 2020; Accepted: 3 June 2020; Published: 4 June 2020

Abstract: (1) Background: Human exposure to organophosphorus compounds employed as pesticides or as chemical warfare agents induces deleterious effects due to cholinesterase inhibition. One therapeutic approach is the reactivation of inhibited acetylcholinesterase by oximes. While currently available oximes are unable to reach the central nervous system to reactivate cholinesterases or to display a wide spectrum of action against the variety of organophosphorus compounds, we aim to identify new reactivators without such drawbacks. (2) Methods: This study gathers an exhaustive work to assess in vitro and in vivo efficacy, and toxicity of a hybrid tetrahydroacridine pyridinaldoxime reactivator, KM297, compared to pralidoxime. (3) Results: Blood-brain barrier crossing assay carried out on a human in vitro model established that KM297 has an endothelial permeability coefficient twice that of pralidoxime. It also presents higher cytotoxicity, particularly on bone marrow-derived cells. Its strong cholinesterase inhibition potency seems to be correlated to its low protective efficacy in mice exposed to paraoxon. Ventilatory monitoring of KM297-treated mice by double-chamber plethysmography shows toxic effects at the selected therapeutic dose. This breathing assessment could help define the No Observed Adverse Effect Level (NOAEL) dose of new oximes which would have a maximum therapeutic effect without any toxic side effects.

Keywords: organophosphorus nerve agents; oxime; cholinesterase; reactivation; ventilation; pharmacodynamics; blood-brain barrier crossing 


\section{Introduction}

The organophosphorus compounds (OP) family includes molecules like parathion used as pesticides, plasticizer, flame retardants, anti-wear additives in jet engine lubricants such as tricresyl phosphate (TCP), as well as highly toxic chemical warfare nerve agents such as VX or sarin. Each year, self-poisonings by OP insecticides lead to around 100,000 deaths worldwide [1]. Recently, attacks were perpetrated with nerve agents in Syria (2013 and 2017) [2,3], Malaysia (2017) [4], and also in the United Kingdom (2018) [5]. The toxic action of these agents is characterized by symptoms such as headache, nausea with vomiting and/or diarrhea, fasciculations progressing to paralysis, loss of consciousness, seizures, and apnea [6]; eventually leading to death. These toxic effects come from the irreversible inhibition of primarily acetylcholinesterase (AChE, E.C. 3.1.1.7) and butyrylcholinesterase (BChE, E.C. 3.1.1.8). Their inhibition results in high concentrations of the acetylcholine neurotransmitter, which leads to the over-stimulation and/or the desensitization of cholinergic receptors located in the synaptic cleft of peripheral and central synapses.

AChE irreversibly inhibited by OP can be reactivated by oximes reactivators (for a review see [7]). Such reactivators associated with an antimuscarinic drug (atropine) and an anticonvulsant (diazepam) form the current emergency treatment in the event of OP poisoning. However, currently marketed oximes do not readily cross the blood-brain barrier (BBB) due to their permanent positive charge. They are, consequently, poorly active in the central nervous system (CNS). Moreover, despite 60 years of research, none of them display an extensive broad spectrum of reactivation [8].

Here we present a toxicological study on human cell lines and a comparative in vivo study in Swiss mice of pralidoxime (2-PAM) with a hybrid tetrahydroacridine pyridinaldoxime reactivator, KM297 (Figure 1), designed to readily cross the BBB and which has shown promising reactivation properties in vitro [9].

Blood clearance of 2-PAM and KM297 as a free base and as various salts are monitored by an established pharmacodynamic method and blood AChE and BChE activity is followed after KM297 chlorhydrate $(\mathrm{HCl})$ injection. Cytotoxicity of 2-PAM and $\mathrm{KM} 297 \mathrm{HCl}$ is assessed on 6 different cell lines. The penetration of both oximes through the BBB is measured using a human in vitro model named brain-like endothelial cells (BLECs) [10]: briefly, their cell toxicity is evaluated using a monolayer integrity marker followed by a permeability test on the BLEC monolayer. Protective efficacy of the oximes without atropine co-treatment is assessed in vivo by $24 \mathrm{~h}$-long-surviving tests in VX-challenged and paraoxon-challenged mice using the up-and-down method; paraoxon being the active and toxic metabolite of parathion. Finally, the toxicity of this novel reactivator is assessed by following the potential of $\mathrm{KM} 297 \mathrm{HCl}$ to alter the breathing pattern of mice.

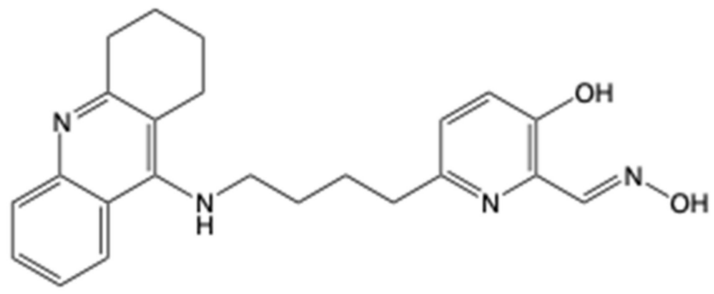

KM297

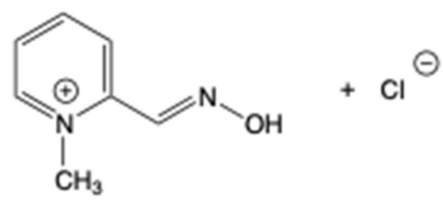

2-PAM

(pralidoxime - chlorhydrate salt)

Figure 1. Chemical structures of the oximes used in this study, the reference oxime 2-PAM, and the novel $\alpha$-hydroxypyridine oxime KM297. 


\section{Materials and Methods}

\subsection{Animals}

We used 8- to 10-week-old male Swiss mice (Janvier, Le Genest-Saint-Isle, France), weighing 37-43 $\mathrm{g}$ at the experimentation time. The animals (3-4/cage) were housed for 7-14 days before the experiments in an environment maintained at $23{ }^{\circ} \mathrm{C}$ with controlled humidity on a $12 \mathrm{~h}$ dark/light cycle with light provided between 7 a.m. and 7 p.m. They were given food and tap water ad libitum. All experiments were carried out in compliance with the European Directive on the protection of animals used for scientific purposes (2010/63/UE) and were approved by our Institutional Animal Care and Research Advisory Committees (2012/22.0 and 12-98).

\subsection{Chemicals}

VX was obtained from DGA maîtrise NRBC (Vert le Petit, France), 2-PAM from Pharmacie Centrale des Armées (Orléans, France), KM297 from UMR CNRS 7515 ICPEES (Strasbourg, France). Heparine, Cremophor-EL, DMSO, iso-OMPA, DTNB, acetylthiocholine, and butyrylthiocholine were purchased from Sigma-Aldrich.

Excluding the cytotoxic study, 2-PAM (chlorhydrate salt) was directly dissolved into physiological serum $(0.9 \% \mathrm{NaCl})$ to obtain the desired concentration (see protocol of each experiment). KM297 free base was first dissolved into DMSO. The solution was then 10-fold-diluted into Cremophor-EL with a final 10 -fold dilution into $0.9 \% \mathrm{NaCl}$ to obtain the final concentration of $1 \% v / v$ DMSO (see protocol of each experiment). The three different salts of KM297, namely chlorhydrate (KM297 $\mathrm{HCl})$, acetate (KM297 AcOH) and methylsulfonate (KM297 MSA) were directly dissolved into $0.9 \%$ saline solution apart from cytotoxic study.

\subsection{Inhibition of AChE by OP Agents}

\subsubsection{Inhibition of Human AChE (hAChE) by VX}

Recombinant hAChE was produced and purified as previously described [11]. The stock solution of VX was $5 \mathrm{mM}$ in isopropanol. Inhibition of purified hAChE at $120 \mu \mathrm{M}$ [12] was achieved with a 5-fold excess of VX (10-fold for standard reactivation curves) in sodium phosphate buffer (0.1 M, $\mathrm{pH} 7.4,0.1 \% \mathrm{BSA}$ ) at $25^{\circ} \mathrm{C}$. Complete inhibition of hAChE was monitored by measuring the residual activity as previously described [13]. After a 20 min-incubation, excess VX was removed by desalting on a PD-10 column (GE Healthcare, Uppsala, Sweden) in the same sodium phosphate buffer.

\subsubsection{Inhibition of Murine AChE (mAChE) by Paraoxon}

Recombinant mAChE was produced and purified as hAChE. The stock solution of paraoxon was $100 \mu \mathrm{M}$ in DMSO. Inhibition of purified mAChE at $113 \mu \mathrm{M}$ [14] was achieved with a 10-fold excess of paraoxon in sodium phosphate buffer $\left(0.1 \mathrm{M}, \mathrm{pH} 7.4,0.1 \%\right.$ BSA) at $25{ }^{\circ} \mathrm{C}$. Complete inhibition of $\mathrm{mAChE}$ was monitored by measuring the residual activity as previously described [13]. After a 15 min-incubation, excess paraoxon was removed by desalting on a PD-10 column (GE Healthcare) in the same sodium phosphate buffer.

\subsection{Plasma Test Protocols}

\subsubsection{Monitoring of the reactivability of blood samples}

This protocol has been previously fully described [15].

Standard Curves of Reactivation

Briefly, VX-inhibited hAChE or paraoxon-inhibited mAChE solution in sodium phosphate buffer was incubated for $30 \mathrm{~min}$ at $37^{\circ} \mathrm{C}$ in the presence of different concentrations of oximes diluted in 
heat-inactivated mice plasma $(0,1,5,10,50,100,150$, and $250 \mu \mathrm{M})$. Ten-microliter aliquots of each sample were transferred to cuvettes containing $1 \mathrm{mM}$ acetylthiocholine in $1 \mathrm{~mL}$ Ellman's buffer (sodium phosphate $0.1 \mathrm{M}, \mathrm{pH} 7.4,0.5 \mathrm{mM} \mathrm{DTNB}, 25^{\circ} \mathrm{C}$ ) for monitoring AChE activity at $412 \mathrm{~nm}$. The percentage of reactivated enzyme (\% $\mathrm{E}_{\text {react }}$ ) (either VX-inhibited hAChE or paraoxon-inhibited $\mathrm{mAChE}$ ) was calculated as the ratio of the recovered OP-inhibited AChE activity and HI-6 reactivated hAChE activity, which is considered as maximal reactivation (i.e., $\% \mathrm{E}_{\text {react }}=100 \%$ ). HI-6 reactivation was achieved by incubating VX-inhibited hAChE with $200 \mu \mathrm{M}$ HI-6 diluted in heat-inactivated plasma. Three independent experiments were carried out for each oxime.

Standard curves were fitted with GraphPad Prism software using a standard asymptotic/ exponential time-dependent reactivation equation giving $\% \mathrm{E}_{\text {react }}$ in the function of the oxime concentration $([\mathrm{Ox}])$ :

$$
\% E_{\text {react }}=100 \times\left(1-e^{-k_{r 2} \times[O x] \times t}\right) \frac{I C_{50}^{n}}{I C_{50}^{n}+[O x]^{n}}
$$

where $\mathrm{k}_{\mathrm{r} 2}$ is the apparent bimolecular rate constant $\left(\mu \mathrm{M}^{-1} \cdot \mathrm{min}^{-1}\right)$ and $\mathrm{t}=30 \mathrm{~min}$ for these series of experiments, $\mathrm{IC}_{50}=0.25 \mu \mathrm{M}$ and $\mathrm{n}$, the Hill coefficient.

\section{Blood Sampling}

At least $24 \mathrm{~h}$ before the experiment, mice were anesthetized with isoflurane gas (Vetflurane ${ }^{\circledR}$, Virbac, France) allowing their hind limbs to be shaved using a 3-min-long application of commercial depilatory cream. Mice were returned to their cages to allow recovery and complete anesthesia washout. On the day of experimentation, mice received intraperitoneal (i.p.) injection of oxime at $23.3 \mu \mathrm{mol} / \mathrm{kg}$, which corresponds to the highest dose of the soluble free base or $100 \mu \mathrm{mol} / \mathrm{kg}$ analogous with our previous studies [15]. At various time-points $(0,2,5,10,15,30,60$, and $180 \mathrm{~min}$ after oxime injection), the saphenous vein was drilled with a needle and approximately $15 \mu \mathrm{L}$ of blood was collected with a heparinized capillary tube and deposited in a collection tube containing $2 \mu \mathrm{L}$ of sodium heparin (Choay ${ }^{\circledR}$, Sanofi, France). Plasma was next isolated from erythrocytes by centrifugation at $4{ }^{\circ} \mathrm{C}, 3000 \mathrm{~g}$ for $10 \mathrm{~min}$. Plasma samples were then heated $30 \mathrm{~min}$ at $56^{\circ} \mathrm{C}$ and treated as previously described in chapter 2.4.1.1. to obtain the percentage of the reactivated enzyme ( $\left.\% \mathrm{E}_{\text {react }}\right)$ with a one-compartment model. $\mathrm{T}_{\max }$ corresponds to the time when the curve reaches a peak of $\% \mathrm{E}_{\text {react }}$. The areas under the percentage of reactivation curve (AUC) and the first-moment curve (AUMC) were calculated using the trapezoidal rule. Mean residence time (MRT) was calculated as the ratio of AUMC to AUC [16].

\subsubsection{Follow-up of Endogenous Blood AChE and BChE Activity}

As in paragraph 2.4.1.2., mice were prepared for blood collection at the same time-points after KM297 HCl i.p. injection at $100 \mu \mathrm{mol} / \mathrm{kg}$. Whole blood samples were diluted 100-fold in sodium phosphate buffer $(0.1 \mathrm{M}, \mathrm{pH} 7.4,0.1 \% \mathrm{BSA})$. Eighteen-microliter aliquots of each sample were transferred to a 96-well plate containing $10 \mathrm{mM}$ acetylthiocholine or butyrylthiocholine in Ellman's buffer with or without iso-OMPA, a BChE inhibitor [17], for a 40-min measurement with a $10 \mathrm{~s}$ time-interval at room temperature for $\mathrm{AChE}$ or $\mathrm{BChE}$ activity respectively.

\subsection{IC 50 of Cholinesterase (ChE) Activity by $\mathrm{KM} 297 \mathrm{HCl}$}

$\mathrm{IC}_{50}$ is the concentration of $\mathrm{KM} 297 \mathrm{HCl}$ that inhibits half of hAChE, $\mathrm{mAChE}$, or human $\mathrm{BChE}$ (hBChE) activity. Recombinant $\mathrm{hBChE}$ was produced in eukaryotic cells as described earlier [18] and the protein purified by BChE specific affinity (Hupresin; CHEMFORASE, Rouen, France) followed by size exclusion chromatography (Superdex 200, GE Healthcare), as previously described [19]. Briefly, $\mathrm{hAChE}, \mathrm{mAChE}$, or hBChE diluted in sodium phosphate buffer was incubated for $1 \mathrm{~min}$ at room temperature with $\mathrm{KM} 297 \mathrm{HCl}$ in Ellman's buffer. Acetylthiocholine or butyrylthiocholine diluted in Ellman's buffer was added to the previous solution and the resulting cholinesterase (ChE) activity was immediately measured using a microplate reader (SPARK, Tecan) at $412 \mathrm{~nm}$ for $1 \mathrm{~min}$. 


\subsection{Cytotoxicity}

\subsubsection{Cell Lines}

Cell lines were purchased from ATTC (Manassas, VA, USA), grown in their respective media and stored as master cell banks and working cell banks. New aliquots were thawed and grown for each experiment. The following cell lines were used:

HEK293 (ATCC CRL-1573): human kidney embryonic epithelial cells HeLa (ATCC CCL-2): human cervix epithelioid carcinoma cells MCF-7 (ATCC HTB-22): human breast adenocarcinoma cells HepG2 (ATTC HB-8065): human liver hepatocellular cells Caco-2 (ATCC HTB-37): human colon adenocarcinoma cells HL-60 (ATCC CCL-240): human promyelocytic leukemia cells

\subsubsection{Cell Culture}

For HEK293, MCF-7, HeLa and HepG2 cells, EMEM (Sigma, St-Quentin Falavier, France, M5650) was used supplemented with $10 \%$ FBS (Invitrogen 10270-106) and the following compounds: 2 mM L-glutamine (PAA-GE-Healthcare, Velizy-Villacoublay, France M11-004), 100 U/mL penicillin/100 $\mathrm{\mu g} / \mathrm{mL}$ streptomycin (Sigma P0781) and $1 \mathrm{mM}$ sodium pyruvate (Invitrogen-Fisher Scientific, Illkirch, France 11360-039). The same medium was employed for Caco-2 cells, but with an increase to $20 \%$ for the FBS (Invitrogen 10270-106).

HL-60 cells were grown in Iscove's Modified Dulbecco's Medium (Sigma 51471C) with 20\% FBS (Invitrogen 10270-106) and $100 \mathrm{U} / \mathrm{mL}$ penicillin/100 $\mu \mathrm{g} / \mathrm{mL}$ streptomycin (Sigma P0781).

Cells were seeded at different concentrations into microtiter plates (Greiner Bio-One, Courtaboeuf, France, 655090) according to cell type using automated multidrop seeder (Thermo Fisher Scientific, Courtaboeuf, France): $5 \times 10^{4}$ cells/well for HeLa and Caco-2 cells, $10^{5}$ cells/well for HEK293 cells, $2 \times 10^{5}$ cells/well for MCF-7 and HepG2 cells, $2.5 \times 10^{5}$ cells/well for HL-60 cells in a volume of $50 \mu \mathrm{L} /$ well.

\subsubsection{Treatment}

$\mathrm{KM} 297 \mathrm{HCl}$ and 2-PAM were dissolved in DMSO at a final concentration of $0.1 \mathrm{M}$. Aliquots were prepared and frozen at $-20{ }^{\circ} \mathrm{C}$ before use. An internal control of cytotoxicity with $50 \mu \mathrm{M}$ chlorpromazine (Sigma C8138) was included in all experiments [20]. After $24 \mathrm{~h}$ of incubation (cell incubator, $37^{\circ} \mathrm{C}, 5 \% \mathrm{CO}_{2}$ ), cells were treated by adding $50 \mu \mathrm{L}$ of medium containing $\mathrm{KM} 297 \mathrm{HCl}$ or 2-PAM (or controls) at twice the final concentration. The dose-response curves were built using the following final concentrations: 100, 30,10,3,1, and $0.3 \mu \mathrm{M}$. All treatments were done using a fully automated robotized platform (Beckman Coulter, Villepinte, France). DMSO concentration was the same in all wells $(0.5 \%$ final).

\subsubsection{Cell Viability Assay}

Cell viability assays were performed $48 \mathrm{~h}$ after treatment. Cell viability was measured using the WST-1 assay (Ozyme, Saint-Quentin-en-Yvelines, France) according to the manufacturer's protocol as described by Houel et al. [21]. Briefly, WST-1-containing medium was added to cells and cell viability was determined by measuring absorbance at $450 \mathrm{~nm}$ using an Envision reader (Perkin Elmer, Villebon-sur-Yvette, France) $1 \mathrm{~h}$ after incubating at $37{ }^{\circ} \mathrm{C}$ and $5 \% \mathrm{CO}_{2}$. Each measurement was performed in triplicate and results were expressed as means of three independent experiments. 
Statistical calculation of $Z^{\prime}$ [22] was performed in all experiments. A $Z^{\prime}>0.5$ confirms that the results were significant and the assay is robust.

$$
Z^{\prime}=1-3 \times \frac{\left(S D_{+}+S D_{-}\right)}{(\text {Mean }+ \text { Mean- })}
$$

where $S D_{+}=$standard deviation of DMSO-treated cells, $S D_{-}=$standard deviation of cytotoxic active control (chlorpromazine), Mean $n_{+}=$mean of DMSO-treated cells, Mean $=$mean of cytotoxic active control.

\subsection{Transport Experiments Across the Human in vitro BBB Model}

\subsubsection{Design of the Human In Vitro BBB Model}

The in vitro model was set up using stem cells as described previously [10]. Endothelial cells were derived from human umbilical cord blood CD $34^{+}$-cells. In accordance with French legislation, the infant's parents signed informed consent. The collection protocol was approved by the French Ministry of Higher Education and Research (CODECOH number DC2011-1321).

Briefly, CD34 ${ }^{+}$-hematopoietic stem cells were isolated and differentiated into endothelial cells as described by Pedroso et al., [23]. Then these endothelial cells were seeded onto matrigel (BD Biosciences, Franklin Lakes, NJ, USA, 354230) coated Transwell inserts (Corning, NY, USA, 3401). Endothelial cells $\left(8 \times 10^{4}\right.$ cells $\left./ \mathrm{cm}^{2}\right)$ were seeded onto the insert and cultured in the presence of $5 \times 10^{4} \mathrm{cells} / \mathrm{cm}^{2}$ bovine brain pericytes seeded at bottom of a well (12-well format). The medium of this co-culture [ECM-5 composed of ECM basal medium (Sciencell, Carlsbad, CA, USA) supplemented with $5 \%(v / v)$ fetal calf serum, $1 \%(v / v)$ EC growth supplement (Sciencell) and $50 \mu \mathrm{g} / \mathrm{mL}$ gentamycin (Biochrom AG, Berlin, Germany)] was renewed every 2 days. After 6 days of co-culture with pericytes, the endothelial cells differentiated into BBB endothelial cells and were ready for experiments. This model named BLECs reproduces several features of the in vivo BBB [24-26].

\subsubsection{Endothelial Permeability Measurement}

Endothelial permeability coefficients were determined as described by Dehouck et al., [27]. The inserts, containing an endothelial cell monolayer or only coated with matrigel, were transferred into 12-well plates containing $1.5 \mathrm{~mL}$ of Ringer-HEPES (RH) buffer saline $(150 \mathrm{mM} \mathrm{NaCl}, 5.2 \mathrm{mM} \mathrm{KCl}$, $2.2 \mathrm{mM} \mathrm{CaCl}_{2}, 0.2 \mathrm{mM} \mathrm{MgCl}_{2} 6 \mathrm{H}_{2} \mathrm{O}, 0.6 \mathrm{mM} \mathrm{NaHCO}_{3}, 5 \mathrm{mM} \mathrm{HEPES}, \mathrm{pH}$ 7.4) per well, thus constituting the abluminal compartment. Then, $0.5 \mathrm{~mL}$ of $\mathrm{RH}$ buffer saline containing $5 \mu \mathrm{M}$ or $50 \mu \mathrm{M}$ of the compound to be tested (2-PAM, KM297 $\mathrm{HCl}$ or diazepam, which easily crosses the BBB and was used as the positive control) was added to the upper (luminal) compartment, in place of the culture medium in contact with the BBB endothelial cells. After different time-points (20, 40, and $60 \mathrm{~min}$ ), filters were transferred into a new well containing RH buffer saline. All incubations were performed at $37^{\circ} \mathrm{C}$. After $60 \mathrm{~min}$, the concentration of the molecules tested was determined in the upper and lower compartments.

To assess the toxicity of the molecules on the BLECs, Lucifer yellow (LY) (Sigma-Aldrich, L0259) that poorly crosses the BBB, was used as the monolayer integrity marker. Diffusion of $50 \mu \mathrm{M} \mathrm{LY}$ was tested alone (control) or incubated with $\mathrm{KM} 297 \mathrm{HCl}$ or 2-PAM, as described above. At $60 \mathrm{~min}$, a $200 \mu \mathrm{L}$ aliquot from a lower compartment at each time point and a $20 \mu \mathrm{L}$ aliquot of the initial solution placed in the upper compartment were put in a fluorimeter (Synergy H1; BioTek, Winooski, VT, USA) for LY concentration measurements or a liquid scintillation counter (Perkin Elmer, Courtabœuf, France) for ${ }^{3} \mathrm{H}$-diazepam measurements, while the concentrations of 2-PAM and $\mathrm{KM} 297 \mathrm{HCl}$ were determined by mass-spectrometry in the solutions from the upper and lower compartments [28].

The endothelial permeability coefficients (Pe) to LY, 2-PAM, KM297 HCl, and diazepam were calculated using the clearance principle to generate a concentration-independent parameter as described by Siflinger-Birnboim et al., [29]. First, the volumes cleared were plotted versus time (20, 40, $60 \mathrm{~min})$ and 
the slopes were estimated by linear regression for both insert only coated with matrigel (PSf) and for insert coated with matrigel and seeded with cells (PSt). PSe was calculated according to the following formula: 1/PSe = 1/PSt-1/PSf where "S" represented the surface area of the porous membrane of the insert. PSe was divided by the membrane surface $\left(1.12 \mathrm{~cm}^{2}\right)$ to generate the endothelial permeability coefficients $(\mathrm{Pe})$ to the studied molecules expressed in $\mathrm{cm} / \mathrm{min}$.

\subsubsection{LC-MS/MS Analysis}

The molecules (2-PAM and KM297 HCl) were analyzed by an LC-MS/MS system consisted of a Thermo Scientific ${ }^{\mathrm{TM}}$ TSQ Vantage ${ }^{\mathrm{TM}}$ Triple Quadrupole mass spectrometer outfitted with a Thermo Accela $^{\mathrm{TM}}$ LC System. The separation was carried out on a Synergi ${ }^{\mathrm{TM}}$ Hydro-RP $80 \AA$ reverse phase column $(3 \times 150 \mathrm{~mm}$, particle size $4 \mu \mathrm{m})$ in isocratic mode using a mixture of water $(\mathrm{A}) /$ acetonitrile (B), both solutions containing $0.1 \%$ formic acid. The mobile phase was delivered through the column (temperature maintained at $35^{\circ} \mathrm{C}$ ) at a flow rate of $0.7 \mathrm{~mL} / \mathrm{min}$, whereas the temperature of the autosampler was kept at $8{ }^{\circ} \mathrm{C}$ with an injection volume of $10 \mu \mathrm{L}$. Chromatographic conditions are summarized in Table 1 . The detection was performed in liquid chromatography-tandem mass spectrometry with a source operating in positive ion mode. The mass spectrometer was used in the multiple reaction monitoring mode (MRM). The precursor/product ion transitions with the highest intensity and/or specificity were selected to give the maximum sensitivity and selectivity for each analyte (Table 2). The acquired MRM data were processed and quantified with Xcalibur ${ }^{\mathrm{TM}}$ software. Each experiment was repeated at least three times.

Table 1. Chromatographic conditions for LC-MS/MS analysis.

\begin{tabular}{ccc}
\hline & KM297 HCl & 2-PAM \\
\hline Column & Synergi Hydro-RP column \\
Mobile phases & $(4 \mu \mathrm{m}, 3 \mathrm{~mm}$ I.D. $\times 150 \mathrm{~mm})$ \\
Isocratic mode & A: water $+0.1 \%$ formic acid, B: acetonitrile $+0.1 \%$ formic acid \\
Flow rate & A: $35 \%-\mathrm{B}: 65 \%$ & A: $99 \%-\mathrm{B}: 1 \%$ \\
Injection volume & $0.7 \mathrm{~mL} / \mathrm{min}$ \\
Total runtime & $10 \mu \mathrm{L}$ \\
\hline
\end{tabular}

Table 2. Multiple reaction monitoring (MRM) transitions and retention times. amu = atomic mass unit.

\begin{tabular}{ccccc}
\hline Compounds & $m / z$ (amu) Q1 & $\begin{array}{c}m / z \text { (amu) Q3 } \\
\text { Quantifier }\end{array}$ & $\begin{array}{c}m / z \text { (amu) Q3 } \\
\text { Qualifier }\end{array}$ & $\begin{array}{c}\text { Retention Time } \\
\text { (min) }\end{array}$ \\
\hline KM297 HCl & 391.3 & 199.1 & 373.3 & 1.5 \\
2-PAM & 137.0 & 119.1 & 93.0 & 2.2 \\
\hline
\end{tabular}

\section{8. $L D_{50}$ Estimation and Protective Index Using the Up-and-Down Method}

$\mathrm{LD}_{50}$ was estimated using the improved method of Dixon's up-and-down procedure described by Rispin et al., [30]. This method uses an iterative dose-selection algorithm. It consists of a single ordered dose progression in which mice are dosed, one at a time, at $24 \mathrm{~h}$ intervals. The first animal receives a dose a step below the level of the best estimate of the $\mathrm{LD}_{50}$. If the mouse survives, the dose for the next animal has increased by 1.1-fold the original dose; if it dies, the dose for the next animal is decreased by the same factor. In our particular conditions, the testing stops when one of the following criteria is met: (1) three consecutive animals survive at the highest dose (which is normally $2000 \mathrm{mg} / \mathrm{kg}$ ); (2) five reversals occur in any six consecutive animals tested; (3) at least four animals have followed the first reversal and the specified likelihood-ratios which compare the maximum likelihood estimate for $\mathrm{LD}_{50}$ with $\mathrm{LD}_{50}$ values above and below exceed the critical value of 2.5. Profile likelihood methods are used to estimate confidence intervals. In practice, the stopping criteria, the resulting $\mathrm{LD}_{50}$, and the corresponding confidence interval were determined using the AOT 425 Pgm software as recommended by OECD [31]. The antidotal efficacy of the oximes is expressed as a protective index (PI) with 95\% confidence interval. The PI corresponds to the ratio of $\mathrm{LD}_{50}$ of the studied OP agent (either VX or 
paraoxon) combined with oxime treatment on $\mathrm{LD}_{50}$ of $\mathrm{OP}$ alone. $\mathrm{LD}_{50}(\mathrm{VX})$ was previously established with a value of $15.4 \mu \mathrm{g} / \mathrm{kg}$ [15].

\subsection{Ventilatory Effect Measurement Using Double-Chamber Plethysmography}

Ventilatory parameters were recorded in a double-chamber plethysmograph (DCP, EMKA Technologies, Paris, France) according to the method described and validated by Nervo et al., [32]. Briefly, this system consists of two interconnected Plexiglas chambers, the head chamber, and the body chamber. The awake mouse is maintained in a conical tube with a small opening to allow the animal's muzzle to pass through. This restrainer is placed into the body chamber, the mouse's muzzle being in the head chamber so that there is no airflow between the two compartments. Each chamber is equipped with a pneumotachograph and a differential pressure transducer. The pneumotachograph ensures the air passages with the outside, while the differential pressure transducer measures the pressure differences between the atmosphere and the relevant compartment. There is a linear relationship between airflow and pressure difference. The mouse breathing leads to two distinct air flows which are simultaneously recorded: i-the nasal flow generated by the airflow in and out of the muzzle; and ii-the thoracic flow generated by compression and expansion of air when the thorax rises and falls. Both chambers are connected to a ventilation pump that removes carbon dioxide and moisture formed inside the chamber.

On the day of the experiment, DCP calibration was performed on two points, high value and a low value by injection of $20 \mathrm{~mL}$ and $0 \mathrm{~mL}$ of air (corresponding to no flow), respectively. The range of measures had to be included between \pm 280 and $\pm 420 \mathrm{~mL} / \mathrm{s}$. The mouse was then placed in the device for a 5-10 min habituation session. Once its spontaneous breathing was calm and regular, the recording was started. The inspiratory time, the expiratory time, the tidal volume, the peak inspiratory flow, the peak expiratory flow, the duration of end-inspiratory pauses and end-expiratory pauses, and the specific airway resistance were continuously measured for 45-50 min using Iox ${ }^{\circledR}$ software (EMKA Technologies, Paris, France) and stored on a computer for subsequent analysis and calculation of additional parameters including the breathing frequency and the minute volume. The first $15 \mathrm{~min}$ of the recording corresponded to the physiological breathing of the mouse and were considered as an internal control. The mouse was then gently removed from the plethysmograph to receive an i.p. injection of $\mathrm{KM} 297 \mathrm{HCl}$ and replaced thereafter in the device for the 30-min remaining measurements. Since two experiments were performed in parallel, the KM297 $\mathrm{HCl}$ administration was delayed by 5 min between the first and the second mouse.

We adapted the up-and-down method previously described in chapter 2.8 to determine the KM297 $\mathrm{HCl}$ dose considered as the "no observed adverse effect level" (NOAEL). Thus, the first group of mice received $100 \mu \mathrm{mol} / \mathrm{kg} \mathrm{KM} 297 \mathrm{HCl}$. A 1.1-fold lower dose was then administered to the next animal. This process was repeated until reaching the dose for which no ventilatory effect was visually observed on the plethysmography traces by the experimenter. At the end of the experiment, the mouse was euthanized by an i.p. lethal injection of sodium pentobarbital (Doléthal ${ }^{\circledR}$, Vétoquinol SA, France).

\subsection{Data Analysis}

Results are expressed as mean \pm SEM.

For the cell viability assays: The $\mathrm{IC}_{50}$ values were calculated using 4 parametric nonlinear regressions by Prism software (version 6.07, GraphPad Software, Inc., San Diego, CA, USA) from the logarithmic dose-response curve.

For transport measurements through the BBB model: Statistical comparisons of the endothelial permeability were performed between $\mathrm{KM} 297 \mathrm{HCl}$ and 2-PAM or diazepam by nonparametric Mann-Whitney test.

For DCP analysis: To study the time-course of ventilatory parameters, the values obtained after $\mathrm{KM} 297 \mathrm{HCl}$ injection were compared to the baseline values at $\mathrm{T}_{-5}-\mathrm{T}_{0}$ time period using Friedman ANOVA followed by multiple comparison tests using Dunn's correction. Thereafter the analysis was 
carried out on a 5-min recording period free of movements of the mouse selected at the peak of the ventilatory effects, i.e., between 10 and $15 \mathrm{~min}$ after the $\mathrm{KM} 297 \mathrm{HCl}$ injection using LabChart software (ADInstruments, Paris, France). For each ventilatory parameter, the normality of data distribution was verified using the Shapiro-Wilk test. The differences between the KM297 $\mathrm{HCl}$ pre-injection and post-injection data were compared using a paired Student's t-tests in case of Gaussian distribution or non-Gaussian Wilcoxon tests. All tests were performed using Prism version 7.0 (GraphPad Software, Inc., San Diego, CA, USA).

For all tests, statistical differences were considered significant when $p<0.05$.

\section{Results}

\subsection{Pharmacodynamic Measurements}

\subsubsection{Based on the Reactivability of OP-Inhibited AChE}

Relying on the method previously reported [15], we established standard curves of 2-PAM and KM297 HCl. While a pralidoxime concentration higher than $200 \mu \mathrm{M}$ allowed to fully reactivate $\mathrm{hAChE}$ and increasing pralidoxime concentrations was correlated with increasing $\mathrm{mAChE}$ reactivation, $\mathrm{KM} 297 \mathrm{HCl}$ effect on both inhibited hAChE and mAChE was only visible at low concentrations. For concentrations higher than $20 \mu \mathrm{M}$, the enzyme reactivation was counterbalanced by a strong inhibition effect (Figure 2). This particular profile of KM297 did not allow us to convert an in situ percentage of AChE reactivation in a unique oxime concentration since a single measured percentage could correspond to two different concentrations, either before or after the reactivation percentage peak.

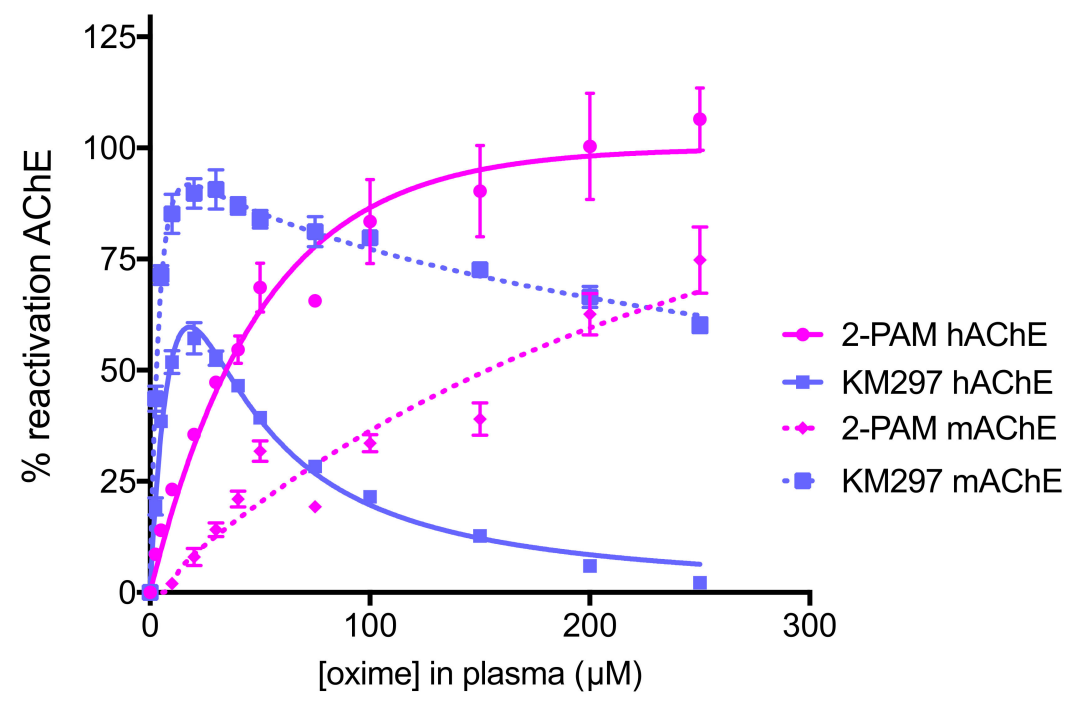

Figure 2. Standard curves of concentration-dependent reactivation of VX-inhibited hAChE and paraoxon-inhibited $\mathrm{mAChE}$ by two oximes. VX-inhibited hAChE and paraoxon-inhibited mAChE were incubated with $0-250 \mu \mathrm{M}$ of oximes (2-PAM or $\mathrm{KM} 297 \mathrm{HCl}$ ) diluted in heat-inactivated mice plasma. The recovered activity was determined after $30 \mathrm{~min}$ incubation at $37^{\circ} \mathrm{C}$. The best-fit curves and apparent bimolecular rate constants $\mathrm{k}_{\mathrm{r} 2}$ were calculated by nonlinear regression using the equation described in part 2.4.1.1 and GraphPad Prism software. Three independent experiments were performed for each oxime and each inhibited enzyme. Values are presented as mean \pm SEM.

In situ clearance of this reactivator followed by in vitro VX-inhibited hAChE reactivation showed that at the same molar concentration (i.e., $23.3 \mu \mathrm{mol} / \mathrm{kg}$ or $10 \mathrm{mg} / \mathrm{kg}$ of KM297 as the free base, which corresponded to its highest concentration completely soluble in $0.9 \% \mathrm{NaCl}$ ) the four galenic forms of the studied oxime presented different pharmacodynamic properties; mainly due to their different reactivation percentage peak. The less soluble free base of the oxime predictably showed 
the lowest maximal reactivation in mice plasma (React $\max =5.1 \pm 1.1 \%$ ), whereas the chlorhydrate salt showed a higher value $(23.0 \pm 2.3 \%)$ than the two other salts $(15.8 \pm 2.9 \%$ for the methylsulfonate vs. $18.6 \pm 2.6 \%$ for the acetate). The time to reach the peak of hAChE reactivation in plasma was around $5 \mathrm{~min}$ for the different salt forms of KM297 (from 3.5 to $6.5 \pm 0.5 \mathrm{~min}$ ). The last parameter established by the reactivability kinetic profile, the mean residence time (MRT), showed that the hAChE reactivability potential of KM297 salts was eliminated from plasma within 23 min compared to $31.0 \pm 3.0 \mathrm{~min}$ for the free base (Figure 3a and Table 3). As the KM297 chlorhydrate salt appeared to be the galenic form with the best pharmacodynamic properties, i.e., with the highest $\mathrm{hAChE}$ reactivation peak together with a long mean residence time, this salt was selected for the subsequent studies. In particular, its pharmacodynamic profile was compared to pralidoxime at the same therapeutic dose of $100 \mu \mathrm{mol} / \mathrm{kg}$. In these conditions, $\mathrm{KM} 297 \mathrm{HCl}$ and 2-PAM showed a similar peak of reactivation ( $57.9 \pm 4.3 \%$ vs. $50.6 \pm 1.7 \%$ respectively), but 2-PAM reached its peak later than KM297 $\mathrm{HCl}$ ( $4.5 \pm 0.5 \mathrm{~min}$ vs. $0.5 \mathrm{~min}$ respectively) which was consistent with a longer persistence in mice plasma $(30.8 \pm 2.8 \mathrm{~min}$ vs. $19.5 \pm 1.1 \mathrm{~min}$ for the MRT respectively) (Figure $3 \mathrm{~b}$ and Table 3$)$.

$23.3 \mu \mathrm{mol} / \mathrm{kg}$

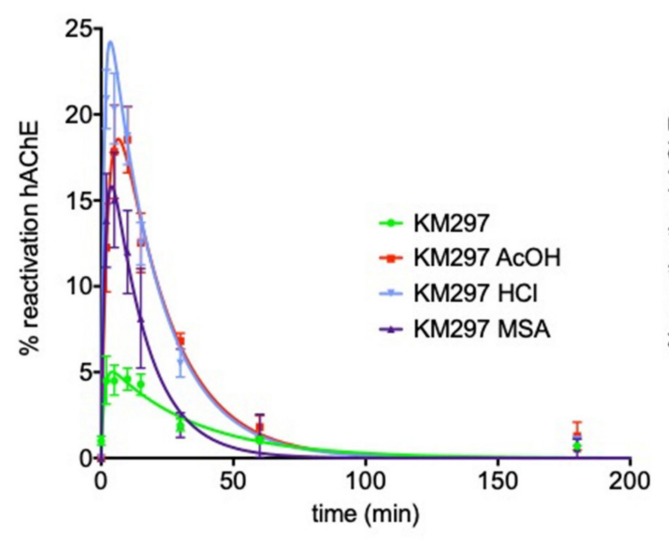

(a)

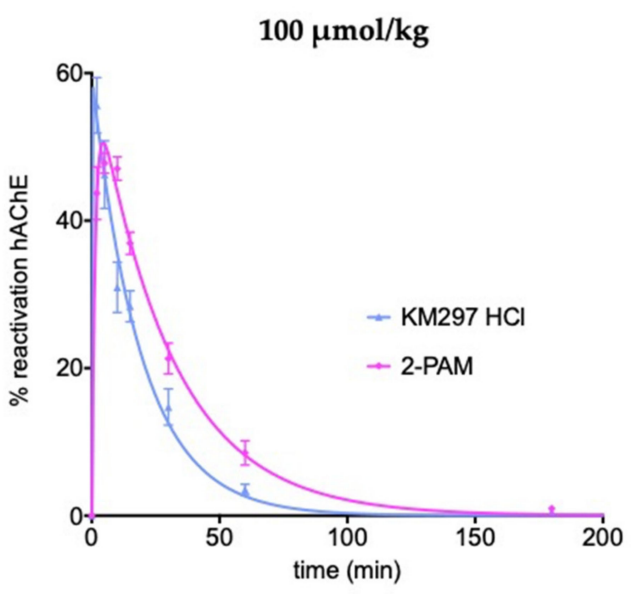

(b)

Figure 3. The reactivability of VX-inhibited hAChE by KM297 as free base and salts, and 2-PAM in mice plasma. (a) The same dose of $23.3 \mu \mathrm{mol} / \mathrm{kg}$ of KM297 free base and salts: acetate $(\mathrm{AcOH})$, chlorhydrate $(\mathrm{HCl})$ and methylsulfonate (MSA) was administered intraperitoneally to mice $(n=8)$. (b) The same dose of $100 \mu \mathrm{mol} / \mathrm{kg}$ of $\mathrm{KM} 297 \mathrm{HCl}$ and 2-PAM was administered intraperitoneally to mice $(n=8-10)$. Blood samples were drawn at various time points $(0,2,5,10,15,30,60$ and $180 \mathrm{~min})$ after treatment, and the levels of reactivation of VX-inhibited hAChE were determined. Values are presented as percentages of maximum reactivation and points are means \pm SEM. Fitting was performed on GraphPad Prism software.

Table 3. MRT: mean residence time, $\mathrm{t}_{\mathrm{max}}$ and React max respectively $\mathrm{x}$ and $\mathrm{y}$ coordinates of the peak of reactivability of VX-inhibited hAChE by KM297 as free base and salts, and 2-PAM in mice plasma presented in Figure 3.

\begin{tabular}{ccccc}
\hline Dose $(\boldsymbol{\mu \mathbf { m o l }} / \mathbf{k g})$ & Oxime & MRT $(\mathbf{m i n})$ & $\mathbf{t}_{\max }(\mathbf{m i n})$ & React Max (\%) \\
\hline 23.3 & KM297 & $31.0 \pm 3.0$ & $5.5 \pm 1.0$ & $5.1 \pm 1.1$ \\
23.3 & $\mathrm{KM} 297 \mathrm{MSA}$ & $15.1 \pm 2.7$ & 4.0 & $15.8 \pm 2.9$ \\
23.3 & $\mathrm{KM} 297$ & $22.4 \pm 0.2$ & $6.5 \pm 0.5$ & $18.6 \pm 2.6$ \\
23.3 & $\mathrm{AcOH}$ & & 3.5 & $23.0 \pm 2.3$ \\
100 & $\mathrm{KM} 297 \mathrm{HCl}$ & $20.2 \pm 0.5$ & 0.5 & $57.9 \pm 4.3$ \\
100 & $\mathrm{KM} 297 \mathrm{HCl}$ & $19.5 \pm 1.1$ & $4.5 \pm 0.5$ & $50.6 \pm 1.7$ \\
\hline
\end{tabular}




\subsubsection{Based on Blood AChE and BChE Activities}

The follow-up of mice blood AChE and BChE activities showed a rapid and significant decrease of plasma BChE activity as early as 2 min after $\mathrm{KM} 297 \mathrm{HCl}$ injection that reached a minimum of $63 \%$ of the initial activity at $10 \mathrm{~min}$ and a slow recovery. Erythrocyte AChE activity decreased more slowly, reached a minimum at $1 \mathrm{~h}$, and remained stable during the $3 \mathrm{~h}$ experiment (Figure 4).

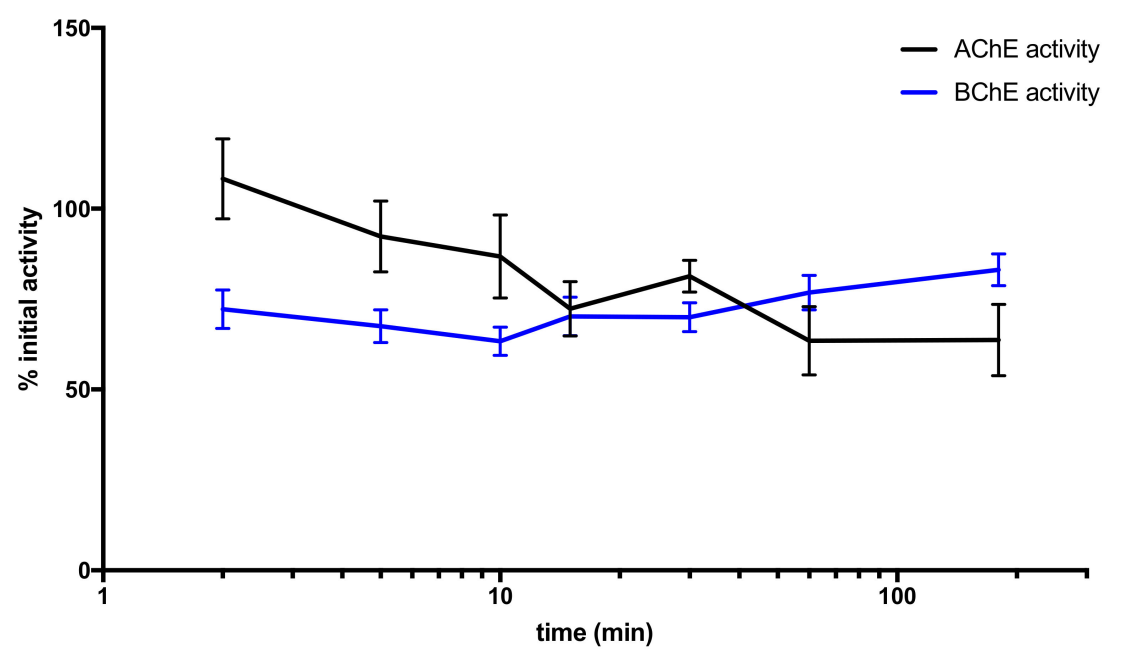

Figure 4. Mice blood $\mathrm{AChE}$ and $\mathrm{BChE}$ activity follow-up after an i.p. administration of $100 \mu \mathrm{mol} / \mathrm{kg}$ $\mathrm{KM} 297 \mathrm{HCl}(n=8-10)$. Blood samples were drawn at various time points $(0,2,5,10,15,30$, 60, and 180 min) after treatment, and $\mathrm{AChE}$ and BChE activity levels were measured. Values are presented as percentages of corresponding initial activity and points are means \pm SEM.

\subsection{IC 50 Measurements of $C h E(h A C h E, m A C h E$, and $h B C h E)$ Activity}

An in vitro determination of the half-maximal inhibitory concentration ( $\left.\mathrm{IC}_{50}\right)$ value of $\mathrm{KM} 297 \mathrm{HCl}$ was performed on recombinant $\mathrm{hAChE}, \mathrm{mAChE}$, and $\mathrm{hBChE}$ to assess its $\mathrm{ChE}$ inhibitor potency. It showed that this oxime induced a 10-fold higher inhibition of hAChE $(0.25 \pm 0.01 \mu \mathrm{M})$ than of $\mathrm{mAChE}(2.5 \pm 0.1 \mu \mathrm{M})$. It is also noteworthy that KM297 is a powerful inhibitor of $\mathrm{hBChE}(11.2 \pm 0.2 \mathrm{nM})$ (Figure 5).

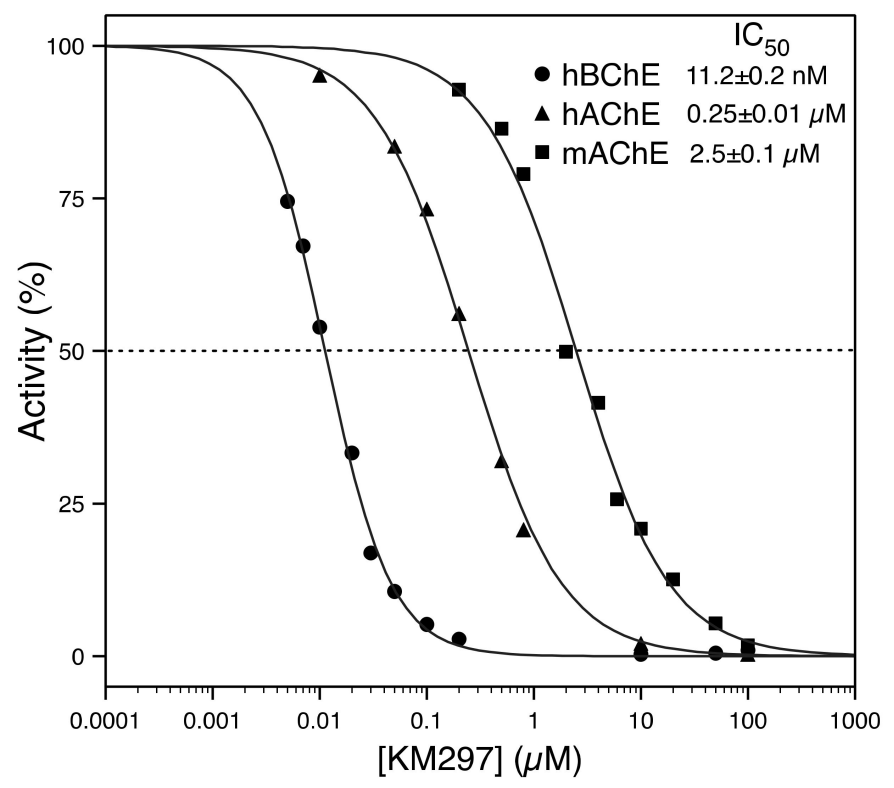

Figure 5. In vitro $\mathrm{IC}_{50}$ determination of $\mathrm{KM} 297 \mathrm{HCl}$ for hAChE, $\mathrm{mAChE}$, and hBChE. 


\subsection{Cytotoxicity}

First of all, it is noteworthy that WST-1 assay does not allow to differentiate proliferation decrease and cell viability. However, a cellular confluency-based assay (imaging assay using Incucyte ${ }^{\circledR}$ apparatus from Sartorius) performed in parallel (data not shown) showed that the cells were dying. Thus, we can affirm that, in our study, the WST-1 assay measured a decrease in cell viability.

While 2-PAM exposure did not induce any deleterious effect on each 6 cell line tested from 0.3 to $100 \mu \mathrm{M}$ of oxime, $\mathrm{KM} 297 \mathrm{HCl}$ exposure induced a decrease of cell viability on each of them at the dose of $100 \mu \mathrm{M}$. Calculated IC S0 $_{5}$ values in each studied cell line are presented in Table 4 . It should be noted that each calculated $Z^{\prime}$ result reached the $\geq 0.5$ value that demonstrates the significance and robustness of the assay. HL60 cells seemed to be the most sensitive to $\mathrm{KM} 297 \mathrm{HCl}$ exposure with an $\mathrm{IC}_{50}$ value of $13.1 \mu \mathrm{M}$. In the HEK293 cell line, the $\mathrm{IC}_{50}$ value was calculated as $45.5 \mu \mathrm{M}$ while in the other cell lines i.e., HeLa, MCF-7, HepG2, and Caco-2 cells, the $\mathrm{IC}_{50}$ was determined to be $75.4,74.3,61.9$, and $65.3 \mu \mathrm{M}$, respectively (Figure 6 and Table 4).

Table 4. IC $_{50}$ values of cell viability WST-1 assay, their respective $95 \%$ confidence interval and calculated $\mathrm{Z}^{\prime}$ value following $\mathrm{KM} 297 \mathrm{HCl}$ exposure of each cell line.

\begin{tabular}{cccc}
\hline Cell Line & IC $_{\mathbf{5 0}}(\boldsymbol{\mu M})$ & $\mathbf{9 5} \%$ Confidence Interval & $\begin{array}{c}\text { Z' Value WST-1/ Positive } \\
\text { Control Chlorpromazine }\end{array}$ \\
\hline HEK293 & 45.5 & {$[38.0 ; 54.4]$} & 0.66 \\
HeLa & 75.4 & {$[34.4 ; 165.5]$} & 0.74 \\
MCF-7 & 74.3 & {$[65.3 ; 84.4]$} & 0.55 \\
HepG2 & 61.9 & {$[50.4 ; 75.9]$} & 0.68 \\
Caco-2 & 65.3 & {$[58.9 ; 72.3]$} & 0.51 \\
HL60 & 13.1 & {$[9.4 ; 18.4]$} & 0.64 \\
\hline
\end{tabular}
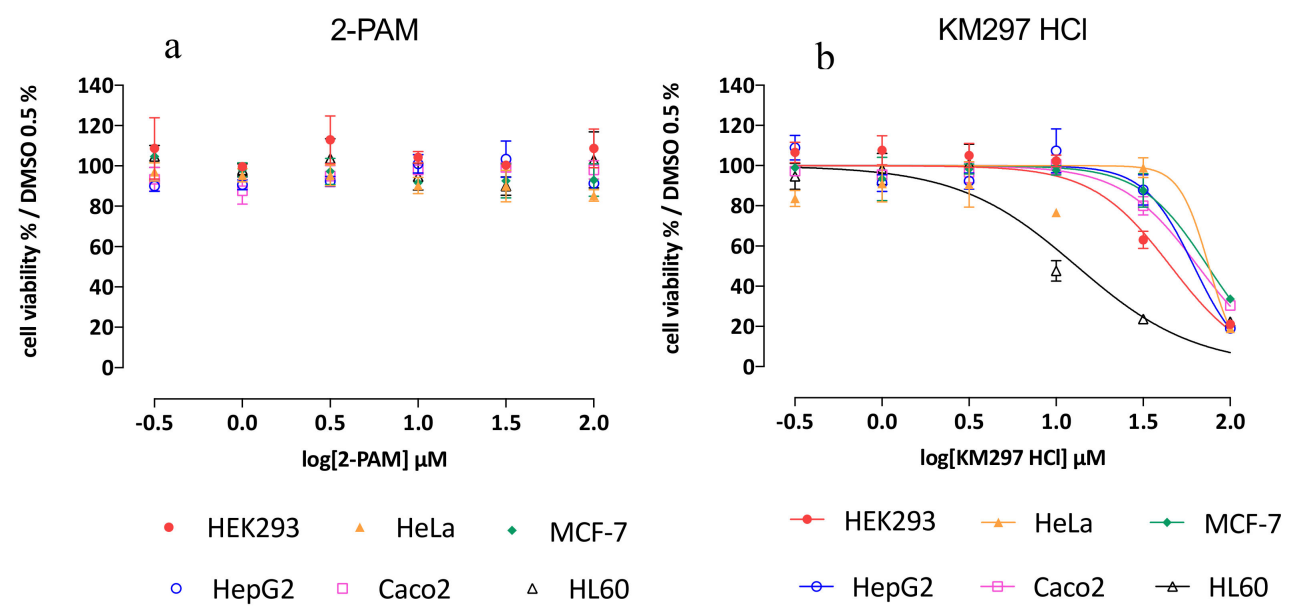

Figure 6. Cell viability WST-1 assay on 6 various cell lines (HEK293, HeLa, MCF-7, HepG2, Caco-2, and HL60 cells) after (a) 2-PAM and (b) KM297 HCl exposure. All experiments were carried out in triplicate and means \pm SEM determined.

\subsection{Transport Assessment Across the Human In Vitro BBB Model}

Before measuring transportation, the toxicity of 2-PAM and $\mathrm{KM} 297 \mathrm{HCl}$ was tested in the human in vitro BBB model. To this extent, the Pe of LY, the small hydrophilic molecule used as BBB integrity marker, incubated with the oximes during the experiment was measured in the presence and absence of oximes. At the dose of 5 and $50 \mu \mathrm{M}, \mathrm{Pe}_{\mathrm{LY}}$ values were equivalent to that obtained for LY incubated alone $\left(\mathrm{Pe}_{\mathrm{LY}}=0.57 \times 10^{-3} \pm 0.04 \mathrm{~cm} / \mathrm{min}\right.$ ), confirming the absence of toxicity of these compounds on the endothelial cell monolayer. 
The passage of 2-PAM and $\mathrm{KM} 297 \mathrm{HCl}$ across BLEC monolayer was assessed using the human in vitro model (Figure 7). The Pe of $\mathrm{KM} 297 \mathrm{HCl}$ was 2- and 1.5-fold greater than that of 2-PAM at the dose of $5 \mu \mathrm{M}$ and $50 \mu \mathrm{M}$, respectively $\left(\mathrm{Pe}_{\mathrm{KM} 297,5 \mu \mathrm{M}}=2.36 \times 10^{-3} \pm 0.49 \mathrm{~cm} / \mathrm{min}\right.$ vs. Pe 2-PAM, $5 \mu \mathrm{M}=1.16 \times 10^{-3} \pm 0.18 \mathrm{~cm} / \mathrm{min}, p=0.001$ and Pe $\mathrm{KM} 297,50 \mu \mathrm{M}=5.35 \times 10^{-3} \pm 0.53 \mathrm{~cm} / \mathrm{min}$ vs. Pe 2-PAM, $50 \mu \mathrm{M}=2.89 \times 10^{-3} \pm 1.81 \mathrm{~cm} / \mathrm{min}, p=0.036$ ).

As brain penetration of a drug such as diazepam is known to be relatively high, Pe values of $\mathrm{KM} 297 \mathrm{HCl}$ were compared with those of diazepam as a positive control. The Pe of $50 \mu \mathrm{M} \mathrm{KM} 297 \mathrm{HCl}$ remained significantly lower than that of diazepam (Pe $\mathrm{KM} 297,50 \mu \mathrm{M}=5.35 \times 10^{-3} \pm 0.53 \mathrm{~cm} / \mathrm{min}$ vs. Pe diazepam, $50 \mu \mathrm{M}=7.54 \times 10^{-3} \pm 0.95 \mathrm{~cm} / \mathrm{min}, p=0.024$ ).

Transport of 2-PAM and $\mathrm{KM} 297 \mathrm{HCl}$ across the human in vitro BBB was concentration-dependent at the dose of 5 and $50 \mu \mathrm{M}$ as endothelial permeability increased with the oximes concentration whereas that of diazepam did not (Table 5).

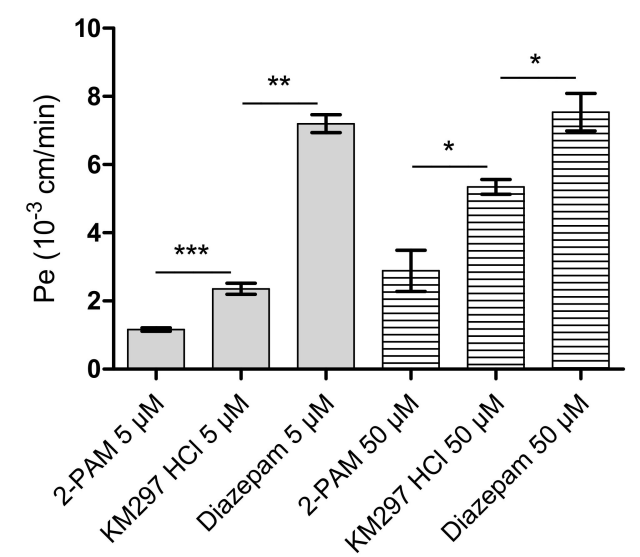

Figure 7. Endothelial permeability coefficient (Pe) of 2-PAM, $\mathrm{KM} 297 \mathrm{HCl}$, and diazepam measured in the human in vitro BBB model at 5 and $50 \mu \mathrm{M}$. Values are presented as mean \pm SEM, $n=3-12$. Comparisons were performed using Mann-Whitney test between $\mathrm{KM} 297 \mathrm{HCl}$ and 2-PAM or diazepam. $\left.{ }^{*} p<0.05,{ }^{* *} p<0.01,{ }^{* * *} p \leq 0.001\right)$.

Table 5. The statistical comparison performed by a nonparametric Mann-Whitney test of the Pe values at 5 and $50 \mu \mathrm{M}$ for 2-PAM, $\mathrm{KM} 297 \mathrm{HCl}$, and diazepam.

\begin{tabular}{ll}
\hline \multicolumn{1}{c}{ 2-PAM } & $p$-Value \\
\hline $5 \mu \mathrm{M}$ vs. $50 \mu \mathrm{M}$ & $0.0076\left(^{* *}\right)$ \\
\hline KM297 $\mathrm{HCl}$ & \\
$5 \mu \mathrm{M}$ vs. $50 \mu \mathrm{M}$ & $0.0004\left(^{* * *}\right)$ \\
\hline Diazepam & \\
$5 \mu \mathrm{M}$ vs. $50 \mu \mathrm{M}$ & 0.7 (ns) \\
\hline
\end{tabular}

\subsection{In Vivo Protective Index Assessment}

Experiments of the up-and-down procedure performed on VX and paraoxon exposure are presented in Tables 6 and 7, respectively. $\mathrm{LD}_{50}(\mathrm{VX})$ was already established previously with a value of $15.4 \mu \mathrm{g} / \mathrm{kg}$ [15]. Intraperitoneal injection of the KM297 free base at the dose of $10 \mathrm{mg} / \mathrm{kg}$ did not show any protection after the VX challenge as demonstrated by the PI equal to 1 (Table 6). $\mathrm{LD}_{50}$ of paraoxon was established to be $796 \mu \mathrm{g} / \mathrm{kg}$. Alone, $100 \mu \mathrm{mol} / \mathrm{kg}$ of 2-PAM induced higher protective efficacy than the same dose of $\mathrm{KM} 297 \mathrm{HCl}$ (PI value of 2.58 and 1.18, respectively). Intraperitoneal treatment with less than a two-thirds dose of $\mathrm{KM} 297 \mathrm{HCl}$ (i.e., $62 \mu \mathrm{mol} / \mathrm{kg}$ ) increased its efficacy after subcutaneous paraoxon challenge $\left(\mathrm{PI}=1.94\right.$ ) (Table 7). $\mathrm{LD}_{50}$ of i.p. injection of $\mathrm{KM} 297 \mathrm{HCl}$ was also assessed by the up-and-down method and achieved a value of $300 \mu \mathrm{mol} / \mathrm{kg}$ (Table 8 ). 
Table 6. $\mathrm{LD}_{50}$ estimation using the up-and-down method for intraperitoneally injected mice at the dose of $10 \mathrm{mg} / \mathrm{kg}$ (i.e., $23.3 \mu \mathrm{mol} / \mathrm{kg}$ ) of KM297 free base one minute after VX subcutaneous challenge.

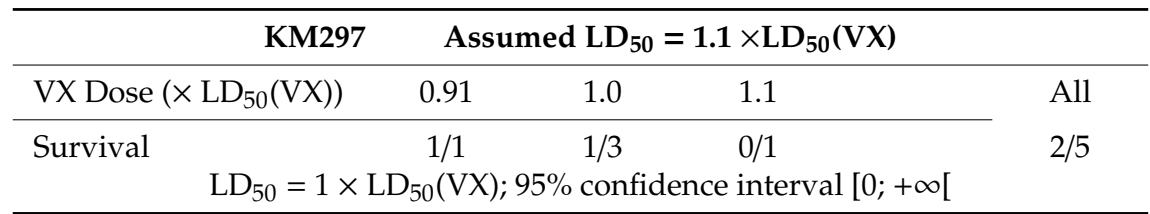

An $\mathrm{LD}_{50}$ value is initially assumed at the beginning of each experiment with sigma $=0.0414(=\log 1.1)$. The $\mathrm{LD}_{50}$ value was calculated using the AOT 425 Pgm software.

Table 7. $\mathrm{LD}_{50}$ estimation using the up-and-down method for untreated mice or injected intraperitoneally at the dose of $100 \mu \mathrm{mol} / \mathrm{kg}$ of 2-PAM or KM297 HCl and $62 \mu \mathrm{mol} / \mathrm{kg}$ of KM297 HCl one minute after paraoxon subcutaneous challenge. An $\mathrm{LD}_{50}$ value is initially assumed at the beginning of each experiment with sigma $=0.0414(=\log 1.1)$. The $\mathrm{LD}_{50}$ values were calculated using the AOT 425 Pgm software.

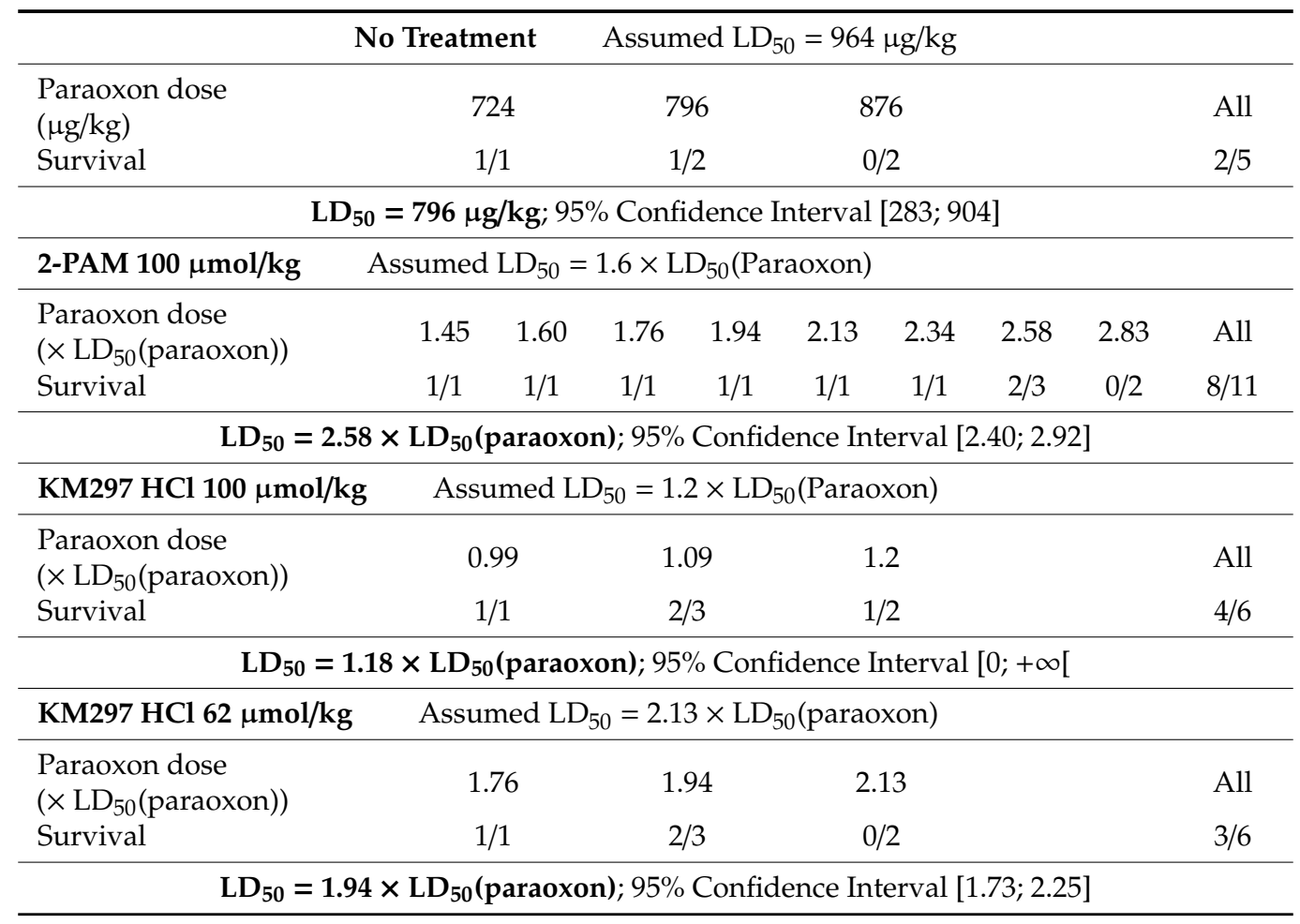

Table 8. $\mathrm{LD}_{50}$ estimation of $\mathrm{KM} 297 \mathrm{HCl}$ using the up-and-down method for injected intraperitoneally mice. An $\mathrm{LD}_{50}$ value of $200 \mu \mathrm{mol} / \mathrm{kg}$ is initially assumed at the beginning of the experiment with sigma $=0.0176(=\log 1.5)$. The $\mathrm{LD}_{50}$ value was calculated using the AOT 425 Pgm software.

\begin{tabular}{cccccc}
\hline No Treatment & \multicolumn{4}{c}{ Assumed $\mathrm{LD}_{50}=200 \mu \mathrm{mol} / \mathrm{kg}$} \\
\hline $\begin{array}{c}\text { KM297 HCl dose } \\
(\mu \mathrm{mol} / \mathrm{kg})\end{array}$ & 133 & 200 & 300 & 450 & All \\
Survival & $1 / 1$ & $2 / 2$ & $1 / 2$ & $0 / 1$ & $4 / 6$ \\
\hline LD $_{50}=\mathbf{3 0 0} \mu \mathrm{mol} / \mathrm{kg} ; 95 \%$ & Confidence Interval $[206 ; 961]$ \\
\hline
\end{tabular}

\subsection{Ventilatory Effect Measurements in Mice}

Thanks to the accurate monitoring of mice ventilation with the DCP system, a NOAEL dose has been determined. This NOAEL corresponds to the highest i.p. injected dose of KM297 $\mathrm{HCl}$ without any observable toxic effects as described below. From the symptomatic dose of $100 \mu \mathrm{mol} / \mathrm{kg}$, we iteratively decreased the dose of the treatment by the same factor of 1.1 . This process was continued 
down to the dose of $62 \mu \mathrm{mol} / \mathrm{kg}$ for which no ventilatory alteration was visually observed by the experimenter. Six different animals were treated at this dose to confirm the lack of visual effect on breathing. As a result, the observed NOAEL is equivalent to approximately one-fifth of the $\mathrm{LD}_{50}$ of $\mathrm{KM} 297 \mathrm{HCl}(300 \mu \mathrm{mol} / \mathrm{kg})$.

Samples of plethysmography recording are presented in Figure 8. For all ventilatory parameters, no significant difference was noticed between both treated groups before $\mathrm{KM} 297 \mathrm{HCl}$ injection (at the dose of $100 \mu \mathrm{mol} / \mathrm{kg}$ and $62 \mu \mathrm{mol} / \mathrm{kg}$ respectively). However, the minute volume was significantly decreased (peak effect: $18.88 \pm 2.80$ vs. $26.67 \pm 3.70 \mathrm{~mL}, p<0.0001$; Figure 9a) probably due to an increase of end-inspiratory pauses duration (peak effect: $40.13 \pm 10.85$ vs. $15.32 \pm 8.48 \mathrm{~ms}, p<0.01$; Figure $9 \mathrm{~b}$ ) for $100 \mu \mathrm{mol} / \mathrm{kg} \mathrm{KM} 297 \mathrm{HCl}$-treated mice compared to the same mice before treatment, (i.e., at the $\mathrm{T}_{-5}-\mathrm{T}_{0}$ reference period). These ventilatory effects started as early as the 5 th minute following $\mathrm{KM} 297 \mathrm{HCl}$ injection, peaked between 10- and 15-min after, for up to $20 \mathrm{~min}$, then gradually decreased over time while remaining present. From these kinetics, the set of ventilatory parameters was then analyzed at the peak of the effects, i.e., at the $\mathrm{T}_{10}-\mathrm{T}_{15}$ time period.
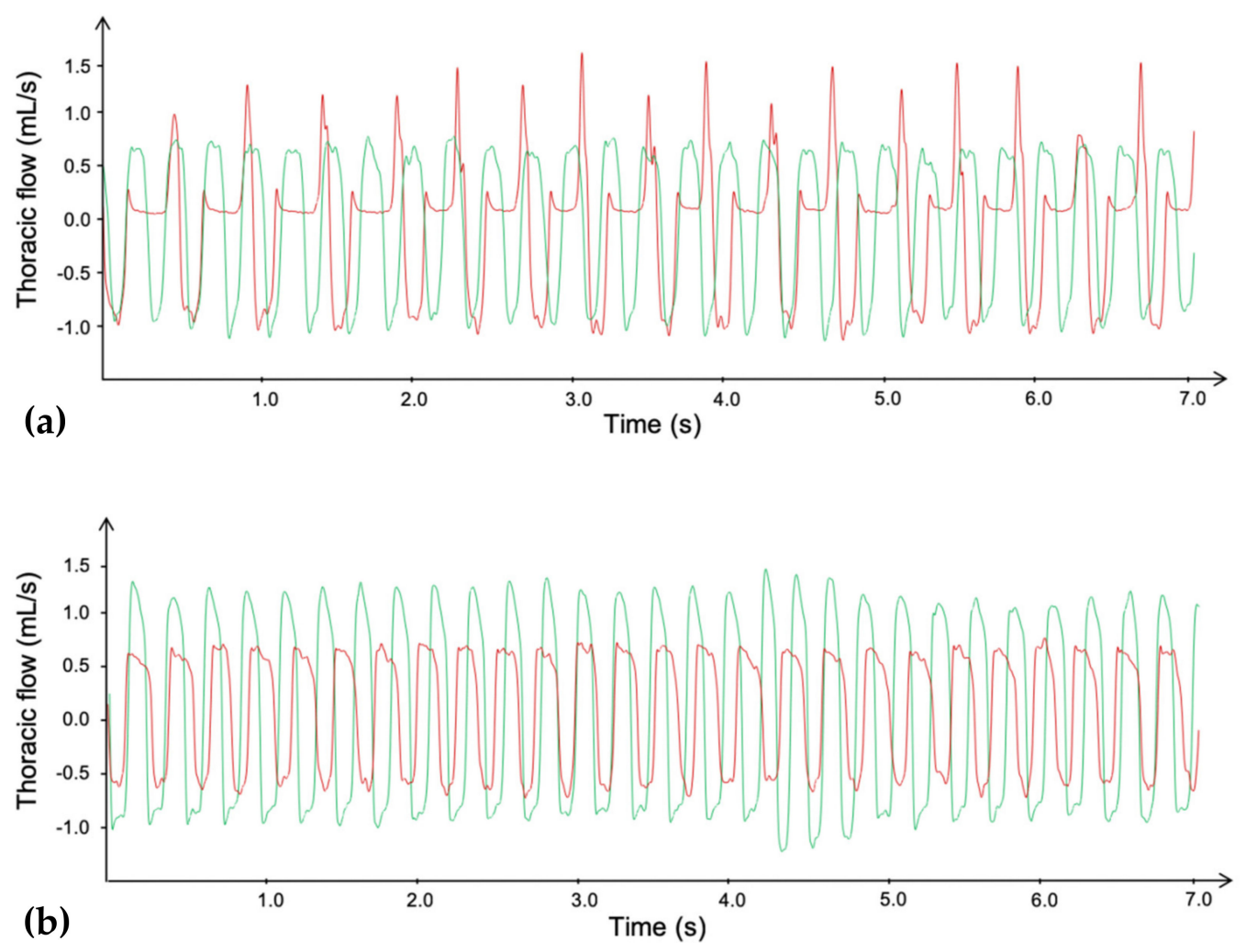

Figure 8. Plethysmography traces of the thoracic flow before (green line) and after (red line) i.p. injection of a dose of $100 \mu \mathrm{mol} / \mathrm{kg}$ (a) or $62 \mu \mathrm{mol} / \mathrm{kg}$ (b) of $\mathrm{KM} 297 \mathrm{HCl}$ in mice. Traces were selected at the peak of the ventilatory effects, i.e., between 10 and $15 \mathrm{~min}$ after the $\mathrm{KM} 297 \mathrm{HCl}$ administration. 


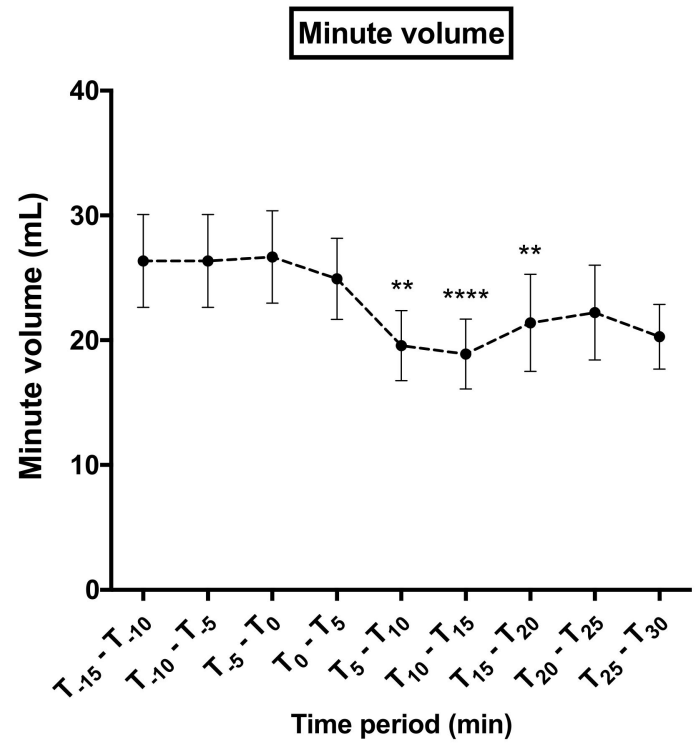

(a)

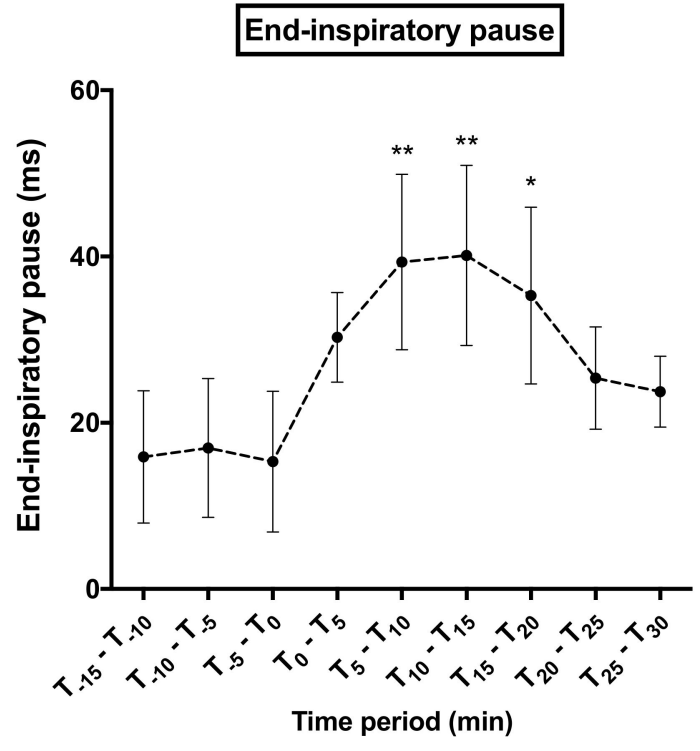

(b)

Figure 9. Time course of minute volume (a) and end-inspiratory pause (b) 15 minutes before $100 \mu \mathrm{mol} / \mathrm{kg}$ $\mathrm{KM} 297 \mathrm{HCl}$ injection up to $30 \mathrm{~min}$ later. Results are presented as the mean of 5 min-means of recordings $\pm \mathrm{SEM}, n=10$. Comparisons were performed using Friedman ANOVA followed by multiple tests using Dunn's correction with $\mathrm{T}_{-5}-\mathrm{T}_{0}$ time period considered as the reference period. ${ }^{*} p<0.05,{ }^{* *} p<0.01$, $* * * * p<0.0001$.

The inspiratory time $(p=0.0323$, Figure $10 \mathrm{a})$ as well as the end-inspiratory pauses duration ( $p=0.0371$, Figure 10c) were significantly increased following $100 \mu \mathrm{mol} / \mathrm{kg} \mathrm{KM} 297 \mathrm{HCl}$ injection in comparison to pre-injection data, while there was no significant difference following $62 \mu \mathrm{mol} / \mathrm{kg} \mathrm{KM} 297$ $\mathrm{HCl}$ administration. In contrast, the peak inspiratory flow ( $p=0.0002$, Figure 10e) and the resulting ventilatory amplitude ( $p=0.0098$, Figure 10f) were significantly decreased following $100 \mu \mathrm{mol} / \mathrm{kg}$ $\mathrm{KM} 297 \mathrm{HCl}$ administration, while no difference was observed regarding the peak inspiratory flow after $62 \mu \mathrm{mol} / \mathrm{kg} \mathrm{KM} 297 \mathrm{HCl}$ injection. With this latter dose the ventilatory amplitude remained reduced $(p=0.0353)$, but with a lower intensity than that of the dose of $100 \mu \mathrm{mol} / \mathrm{kg}(5.6 \% \mathrm{vs} .19 .8 \%$ respectively). A marked reduction in the tidal volume ( $p=0.0020$, Figure $10 \mathrm{~d}$ ) and the resulting minute volume ( $p=0.0002$, Figure $10 \mathrm{~b}$ ) was also noticed following $100 \mu \mathrm{mol} / \mathrm{kg} \mathrm{KM} 297 \mathrm{HCl}$ injection, and persisted with a lower intensity after the administration of the dose of $62 \mu \mathrm{mol} / \mathrm{kg}(20.4 \% \mathrm{vs}$. $10 \%$ respectively for the tidal volume, $p=0.0435 ; 29 \%$ vs. $11.4 \%$ respectively for the minute volume, $p=0.0129$ ). Other ventilatory parameters remained unchanged (data not shown). 


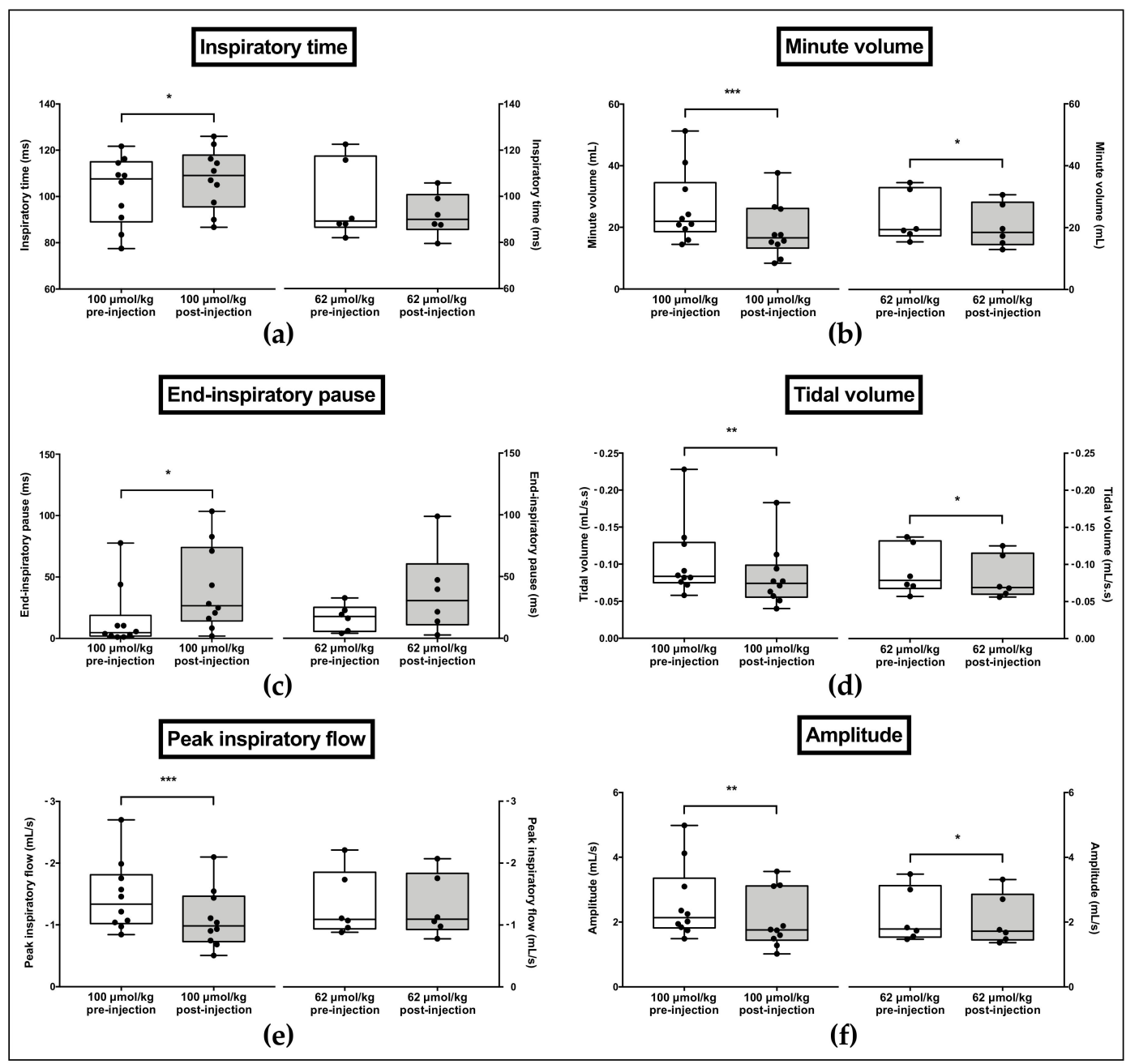

Figure 10. Effects of i.p. administration of $100 \mu \mathrm{mol} / \mathrm{kg}$ or $62 \mu \mathrm{mol} / \mathrm{kg} \mathrm{KM} 297 \mathrm{HCl}$ on ventilatory parameters recorded by double-chamber plethysmography: inspiratory time (a), minute volume (b), end-inspiratory pause (c), tidal volume (d), peak inspiratory flow (e) and amplitude (f). $n=6-10$. The line in the middle of the box is plotted at the median. Each individual value is represented as black circles. Whiskers range from the maximum value to minimum value. Comparisons were performed using paired t-tests for normally distributed variables or Wilcoxon tests in case of non-Gaussian distribution. ${ }^{*} p<0.05,{ }^{* *} p<0.01,{ }^{* * *} p<0.001$.

\section{Discussion}

KM297 is an uncharged reactivator of OP-inhibited AChE based on tetrahydroacridine pyridine-aldoxime hybrids [9,33]. Its tacrine scaffold has been recently identified as relevant against an OP pesticide poisoning [34]. Designed to cross the BBB, the high lipophilicity of the free base leads to poor solubility [35]: $10 \mathrm{mg} / \mathrm{kg}$ (i.e., $23.3 \mu \mathrm{mol} / \mathrm{kg}$ ) is the highest achievable concentration in $1 \% \mathrm{DMSO}, 10 \%$ Cremophor-EL, $0.9 \% \mathrm{NaCl}$. Unfavorable pharmacodynamics of the free base (React-max $=5.1 \pm 1.1 \%$ ) is coherent with an absence of in vivo protection against a VX challenge $(\mathrm{PI}=1)$. This is in agreement with the correlation between pharmacodynamic data and protective efficacy reported earlier [15].

New formulations with higher solubility in water such as MSA, $\mathrm{AcOH}$, or $\mathrm{HCl}$ salts have been assessed. They present at least 3-fold higher maximal reactivation of VX-inhibited hAChE at their respective $t_{\max }$ (React-max value equals to $15.8 \% \pm 2.9 \%, 18.6 \% \pm 2.6 \%$ and $23.0 \% \pm 2.3 \%$, respectively) when injected at the same dose of $23.3 \mu \mathrm{mol} / \mathrm{kg}$. Due to its more favorable pharmacodynamic profile, the $\mathrm{HCl}$ salt was selected for further assessments. 
We have shown that the strong reversible inhibition of AChE by KM297 HCl prevents the correlation between pharmacodynamics and pharmacokinetics since one percentage of reactivation could correspond to two oxime concentrations in the standard curve of reactivation. The paraoxon-inhibited mAChE reactivation curve by $\mathrm{KM} 297 \mathrm{HCl}$ presents a similar pharmacodynamic profile which is consistent with the 10-fold higher $\mathrm{IC}_{50}$ value measured with $\mathrm{mAChE}$ as compared to the one from hAChE. It is worth noting that the 20 -fold lower calculated IC $_{50}$ value with $\mathrm{hBChE}$ versus $\mathrm{hAChE}$ prevents $\mathrm{BChE}$ from playing a back-up role in acetylcholine hydrolysis in the case of $\mathrm{AChE}$ inhibition. Interestingly, the inhibition property of KM297 could be used as an alternative for reactivation to estimate its plasma concentration. The $\mathrm{IC}_{50}$ curve could then allow the correlation of a percentage of inhibition of AChE to a concentration of oxime.

However, in vivo protective efficacy of $\mathrm{KM} 297 \mathrm{HCl}$ after paraoxon challenge seems to be completely uncorrelated to its maximal percentage of reactivation. Indeed, the same therapeutic dose fixed at $100 \mu \mathrm{mol} / \mathrm{kg} \mathrm{KM} 297 \mathrm{HCl}$ shows a similar pharmacodynamic profile to that of 2-PAM but a different protective index: respectively 1.18 and 2.58 . We can reject that this disparity is due to the lack of cerebral effect since our in vitro BBB model established that, as with 2-PAM, KM297 HCl does not affect BBB integrity, though at the same high dose (i.e., $50 \mu \mathrm{M}) \mathrm{KM} 297 \mathrm{HCl}$ induces cytotoxic effect on several cell lines. This apparent discrepancy can be explained by the huge temporal difference between both observations: endothelial cell monolayer integrity is assessed only 60 min after KM297 $\mathrm{HCl}$ exposure while cell line toxicity is measured $48 \mathrm{~h}$ post-exposure. Second, this model established that the permeability of $\mathrm{KM} 297 \mathrm{HCl}$ is 2-fold higher than 2-PAM, although lower than the positive control diazepam. Furthermore, 2-PAM and $\mathrm{KM} 297 \mathrm{HCl}$ cross the in vitro BBB in a dose-dependent manner, as already described for 2-PAM using in vivo rat brain microdialysis technique [36].

The potential cytotoxicity and/or systemic toxicity of KM297 could eventually explain its low protective efficacy against OP exposure. Cytotoxicity was evaluated in 6 different human cell lines, each related to different organs: HEK293 to the kidney, HeLa to the uterus, MCF-7 to the breast, HepG2 to the liver, Caco-2 to the colon, HL-60 to the bone marrow. Whereas 2-PAM does not seem to induce any cytotoxicity regardless of the cell line and the concentration of oxime considered, $\mathrm{KM} 297 \mathrm{HCl}$ appears most cytotoxic to HL-60 cells with an $\mathrm{IC}_{50}$ of $13.1 \mu \mathrm{M}$, followed by HEK293 and then to the four other cell lines: HeLa, HepG2, Caco-2 and MCF-7 cells with similar IC 50 values greater than $61 \mu \mathrm{M}$. By contrast, the $\mathrm{IC}_{50}$ of 2-PAM in the HepG2 cell line was $22.8 \mathrm{mM}$ [37]. $\mathrm{KM} 297 \mathrm{HCl}$ appears to be almost 400-fold more cytotoxic than the reference oxime. Bone marrow and consequently blood cells seem to be the most sensitive cells to KM297 HCl. Other tacrine-derived oximes show similar toxicity on HepG2 cells than tacrine [34]. The tacrine scaffold has also been shown, among others, to play a role in hepatotoxicity [38] even if by way of a metabolite [39].

We evaluated the systemic toxicity of $\mathrm{KM} 297 \mathrm{HCl}$ through i.p. injection by measuring the $\mathrm{LD}_{50}$ at $24 \mathrm{~h}$ with the up-and-down procedure. With an $\mathrm{LD}_{50}$ at $300 \mu \mathrm{mol} / \mathrm{kg}, \mathrm{KM} 297 \mathrm{HCl}$ is 3-fold more toxic than 2-PAM delivered intramuscularly in the same Swiss male mice $\left(\mathrm{LD}_{50}(2-\mathrm{PAM})=1 \mathrm{mmol} / \mathrm{kg}\right)$ [40]. In other words, the therapeutic dose of $100 \mu \mathrm{mol} / \mathrm{kg}$ chosen to compare the protective efficacy of various oximes is $1 / 3 \mathrm{rd}$ of the $\mathrm{LD}_{50}(\mathrm{KM} 297 \mathrm{HCl})$ whereas it is only $1 / 10$ th of $\mathrm{LD}_{50}(2-\mathrm{PAM})$.

In addition, mice that received an i.p. injection of $\mathrm{KM} 297 \mathrm{HCl}$ at the dose of $100 \mu \mathrm{mol} / \mathrm{kg}$ showed some characteristic preliminary symptoms related to $\mathrm{ChE}$ inhibition such as hypotonia (data not shown). To estimate the level of $\mathrm{AChE}$ and BChE inhibition after i.p. injection of $\mathrm{KM} 297 \mathrm{HCl}$ in mice in the absence of OP exposure, we monitored blood AChE and BChE activities. We expected that the time at maximal inhibition of erythrocyte $\mathrm{AChE}$ and plasma $\mathrm{BChE}$ activities would match that of maximal reactivability seen in the pharmacodynamic curve, as both measurements are proxies of the actual concentration of circulating KM297 HCl. Yet blood AChE activity reached a minima of $60 \mathrm{~min}$ after $\mathrm{KM} 297 \mathrm{HCl}$ injection, and plasma BChE activity reached a minima of $10 \mathrm{~min}$ after injection, whereas maximal reactivation of VX-inhibited hAChE peaks only $30 \mathrm{~s}$ after the injection. However, the dual reactivation/inhibition activity of $\mathrm{KM} 297 \mathrm{HCl}$ could hamper the correct estimation of the time at the peak of reactivation as larger concentrations induce strong inhibition that cancels out the recovery of 
activity due to reactivation. A longer persistence of this oxime and a delayed peak of concentration of $\mathrm{KM} 297 \mathrm{HCl}$ in the blood compartment could explain this incongruity.

Either method, pharmacodynamics based on reactivability power or inhibition, reports the blood compartment time-evolution of different states of the oxime: bound to $\mathrm{ChE}$ for the inhibition method or free oxime for the reactivability method. Consequently, by gathering these results and by taking into account the inhibition potency of $\mathrm{KM} 297 \mathrm{HCl}$ in the reactivability pharmacodynamic data, it is established that this oxime penetrates rapidly into the blood compartment and has a sufficiently low clearance to inhibit a significant portion of circulating AChE and BChE for hours. This long lifetime is corroborated by DCP results, which show a persistence of ventilatory alterations, thought to be related to ChE inhibition (see below), beyond the mean residence time in blood measured as measured by the reactivability method $(20 \mathrm{~min})$. Naturally, it must be considered that the DCP results and blood pharmacokinetic data do not show the inhibition of the same compartment i.e., lung vs. blood. Nevertheless, the difference between these two proxy-based estimates of the actual circulating concentration of oximes confirms the main deficiency of the reactivability assay which lies in its inability to take into account the intrinsic inhibition potency of the oxime. In this case, a chemical analytical method to directly measure the concentration of oximes is necessary.

$\mathrm{ChE}$ inhibitors such as OP compounds or carbamates may provoke death by respiratory arrest. Breath monitoring with a DCP system confirms that a dose of $100 \mu \mathrm{mol} / \mathrm{kg}$ of $\mathrm{KM} 297 \mathrm{HCl}$ i.p. alters ventilation. In particular, this dose of $\mathrm{KM} 297 \mathrm{HCl}$ induces a significant increase in inspiratory time correlated to the appearance of end-inspiratory pauses. These alterations have previously been established on the breathing of mice challenged with paraoxon and physostigmine, a carbamate inhibitor of AChE [32]. These breathing alterations after administration of a dose of $100 \mu \mathrm{mol} / \mathrm{kg}$ $\mathrm{KM} 297 \mathrm{HCl}$ can be correlated to its potency to inhibit ChE. Indeed, significant differences of minute volume and end-inspiratory pauses duration appear around $10 \mathrm{~min}$ after oxime injection, when the inhibition of plasmatic BChE activity is the highest, which means when $\mathrm{BChE}$ is no longer able to protect the ventilatory system from the toxic effects of a high circulating acetylcholine concentration [32]. Moreover, we determined the NOAEL at $62 \mu \mathrm{mol} / \mathrm{kg}$ or approximately one-fifth of the $\mathrm{LD}_{50}$ of KM297 $\mathrm{HCl}(300 \mu \mathrm{mol} / \mathrm{kg})$.

It is more relevant to treat OP-exposed animals with an equitoxic dose of reactivator as reported earlier [41,42], rather than use an equimolar dose of reactivator. But instead of applying an arbitrary factor of $\mathrm{LD}_{50}$ to determine the equitoxic dose, we determine the NOAEL dose for each reactivator, based on the alteration of ventilatory parameters relevant to ChE inhibition. Regarding the criteria for establishing the NOAEL dose, even if ventilatory parameters such as inspiratory time and end-inspiratory pause duration increase or peak inspiratory flow decrease are no longer noticeable, other parameter modifications persist such as tidal volume and minute volume and amplitude decrease. The latter are, however, lower than those measured at the dose of $100 \mu \mathrm{mol} / \mathrm{kg}$. It seems that the visual assessment of ventilation cycle alterations does not appear to be completely accurate in comparison to the calculation of all the different breathing parameters. It seems sufficient to establish a more effective therapeutic dose since there is a significant increase of the protection brought by the KM297 $\mathrm{HCl}$ treatment: PI increases from 1.18 at $100 \mu \mathrm{mol} / \mathrm{kg}$ to 1.94 at $62 \mu \mathrm{mol} / \mathrm{kg}$. A higher protective efficacy with a lower dose has previously been described with other oximes [41]. This result combined with cytotoxic data attests to the narrowness of the therapeutic window of $\mathrm{KM} 297 \mathrm{HCl}$.

\section{Conclusions}

We improved the solubility and bioavailability of KM297 with salt derivatives, the most favorable being the chlorhydrate salt. As performed here with $\mathrm{KM} 297 \mathrm{HCl}$, inhibition potency of oximes could be identified by using the DCP system, which proves its ability to accurately detect minute ventilatory alterations related to $\mathrm{ChE}$ inhibition. This system also allows the establishment of a suitable therapeutic dose: we hypothesize that $20 \%\left(\mathrm{LD}_{50}\right.$ (oxime)) would correspond to its NOAEL value, which should be used as a therapeutic dose in follow-on studies. 
Finally, even if the strong ChE inhibition induced by $\mathrm{KM} 297 \mathrm{HCl}$ should disqualify it as a drug for emergency treatment, its potency in temporarily masking $\mathrm{ChE}$ sites from nerve agents, associated with its ability to cross BBB to reach the CNS targets as huperzine does [43], as well as its long-lasting persistence as a reversible adduct with $\mathrm{ChE}$ in at least the blood compartment, and of course, its ability to reactivate $\mathrm{OP}$-inhibited $\mathrm{ChE}$ could conversely qualify it as an efficient prophylactic treatment for $\mathrm{OP}$ nerve agents.

Author Contributions: Conceptualization, A.-G.C. and F.N.; KM297 synthesis, M.K., J.Y., and R.B.; cytotoxicity experiments, A.O. and P.V.; in vivo pharmacokinetic and pharmacodynamic experiments C.R., C.C., and A.-G.C.; $\mathrm{IC}_{50}$ measurement C.C., X.B., F.N., and J.D.; $\mathrm{LD}_{50}$ and protective index estimation A.-G.C., C.R., and C.C.; transport experiments across human in vitro BBB model, J.-F.G., C.L., J.H., F.G., and M.-P.D., ventilatory effect measurements A.-S.H., A.N., and N.J.; writing—original draft preparation, A.-G.C.; writing—review and editing, C.C., A.-S.H., A.N., J.D., C.R., A.O., P.V., J.-F.G., C.L., J.H., F.G., M.-P.D., J.Y., M.K., R.B., X.B., N.J., and F.N.; supervision, F.N.; project administration, F.N., A.-G.C., and J.D. All authors have read and agreed to the published version of the manuscript.

Funding: This research was funded by the French Ministry of Armed Forces (Direction Générale de l'Armement and Service de Santé des Armées) under contracts PDH-2-NRBC-4-C-4203 and NBC-5-C-4210 and by ANR under contract CNS-Antidote (ANR-17-CE39-0012). Cytotoxicity: This work has benefited from an Investissement d'Avenir grant of the ANR (LABEX ANR-10-LABX-0034_Medalis).

Acknowledgments: CNRS and the University of Strasbourg are acknowledged for support. The authors are grateful to Joseph Kononchik for his critical reading and editing of the manuscript.

Conflicts of Interest: The authors declare no conflict of interest.

\section{References}

1. Eddleston, M. Novel Clinical Toxicology and Pharmacology of Organophosphorus Insecticide Self-Poisoning. Annu. Rev. Pharmacol. Toxicol. 2019, 59, 341-360. [CrossRef]

2. John, H.; Van Der Schans, M.J.; Koller, M.; Spruit, H.E.T.; Worek, F.; Thiermann, H.; Noort, D. Fatal sarin poisoning in Syria 2013: Forensic verification within an international laboratory network. Forensic Toxicol. 2017, 36, 61-71. [CrossRef] [PubMed]

3. OPCW.org. OPCW Confirms Use of Sarin and Chlorine in Ltamenah, Syria, on 24 and 25 March 2017. Available online: https://www.opcw.org/media-centre/news/2018/06/opcw-confirms-use-sarin-and-chlorineltamenah-syria-24-and-25-march-2017 (accessed on 13 June 2018).

4. Patočka, J. What killed Kim Jong-Nam? Was it the agent VX? Mil. Med. Sci. Lett. 2017, 86, 86-89. [CrossRef]

5. Carlsen, L. After Salisbury Nerve Agents Revisited. Mol. Informatics 2018, 38, 8-9. [CrossRef]

6. Cannard, K. The acute treatment of nerve agent exposure. J. Neurol. Sci. 2006, 249, 86-94. [CrossRef]

7. Mercey, G.; Verdelet, T.; Renou, J.; Kliachyna, M.; Baati, R.; Nachon, F.; Jean, L.; Renard, P.-Y. Reactivators of Acetylcholinesterase Inhibited by Organophosphorus Nerve Agents. Accounts Chem. Res. 2012, 45, 756-766. [CrossRef]

8. Worek, F.; Thiermann, H.; Wille, T. Oximes in organophosphate poisoning: 60 years of hope and despair. Chem. Interactions 2016, 259, 93-98. [CrossRef]

9. Kliachyna, M.; Santoni, G.; Nussbaum, V.; Renou, J.; Sanson, B.; Colletier, J.-P.; Arboléas, M.; Loiodice, M.; Weik, M.; Jean, L.; et al. Design, synthesis and biological evaluation of novel tetrahydroacridine pyridinealdoxime and -amidoxime hybrids as efficient uncharged reactivators of nerve agent-inhibited human acetylcholinesterase. Eur. J. Med. Chem. 2014, 78, 455-467. [CrossRef] [PubMed]

10. Cecchelli, R.; Aday, S.; Sevin, E.; Almeida, C.; Culot, M.; Dehouck, L.; Coisne, C.; Engelhardt, B.; Dehouck, M.-P.; Ferreira, L. A Stable and Reproducible Human Blood-Brain Barrier Model Derived from Hematopoietic Stem Cells. PLoS ONE 2014, 9, e99733. [CrossRef]

11. Zueva, I.; Dias, J.; Lushchekina, S.V.; Semenov, V.; Mukhamedyarov, M.; Pashirova, T.; Babaev, V.; Nachon, F.; Petrova, N.; Nurullin, L.; et al. New evidence for dual binding site inhibitors of acetylcholinesterase as improved drugs for treatment of Alzheimer's disease. Neuropharmacol. 2019, 155, 131-141. [CrossRef]

12. Carletti, E.; Li, H.; Li, B.; EkströmF; Nicolet, Y.; Loiodice, M.; Gillon, E.; Froment, M.T.; Lockridge, O.; Schopfer, L.M.; et al. Aging of Cholinesterases Phosphylated by Tabun Proceeds through O-Dealkylation. J. Am. Chem. Soc. 2008, 130, 16011-16020. [CrossRef] [PubMed] 
13. Ellman, G.L.; Courtney, K.; Andres, V.; Featherstone, R.M. A new and rapid colorimetric determination of acetylcholinesterase activity. Biochem. Pharmacol. 1961, 7, 88-95. [CrossRef]

14. Ronco, C.; Carletti, E.; Colletier, J.-P.; Weik, M.; Nachon, F.; Jean, L.; Renard, P.-Y. Huprine Derivatives as Sub-Nanomolar Human Acetylcholinesterase Inhibitors: From Rational Design to Validation by X-ray Crystallography. ChemMedChem 2011, 7, 400-405. [CrossRef] [PubMed]

15. Calas, A.-G.; Dias, J.; Rousseau, C.; Arboléas, M.; Touvrey-Loiodice, M.; Mercey, G.; Jean, L.; Renard, P.-Y.; Nachon, F. An easy method for the determination of active concentrations of cholinesterase reactivators in blood samples: Application to the efficacy assessment of non quaternary reactivators compared to HI- 6 and pralidoxime in VX-poisoned mice. Chem. Interactions 2017, 267, 11-16. [CrossRef]

16. Kwon, Y. Handbook of Essential Pharmacokinetics, Pharmacodynamics and Drug Metabolism for Industrial Scientists; Springer: Boston, MA, USA, 2007; p 1 online resource; 302p.

17. Dingova, D.; Leroy, J.; Check, A.; Garaj, V.; Krejci, E.; Hrabovska, A. Optimal detection of cholinesterase activity in biological samples: Modifications to the standard Ellman's assay. Anal. Biochem. 2014, 462, 67-75. [CrossRef]

18. Nachon, F.; Nicolet, Y.; Viguié, N.; Masson, P.; Fontecilla-Camps, J.-C.; Lockridge, O. Engineering of a monomeric and low-glycosylated form of human butyrylcholinesterase. JBIC J. Boil. Inorg. Chem. 2002, 269, 630-637. [CrossRef]

19. Brazzolotto, X.; Wandhammer, M.; Ronco, C.; Trovaslet, M.; Jean, L.; Lockridge, O.; Renard, P.-Y.; Nachon, F. Human butyrylcholinesterase produced in insect cells: Huprine-based affinity purification and crystal structure. FEBS J. 2012, 279, 2905-2916. [CrossRef]

20. Dudani, A.K.; Gupta, R.S. Effect of chlorpromazine and trifluoperazine on cytoskeletal components and mitochondria in cultured mammalian cells. Tissue Cell 1987, 19, 183-196. [CrossRef]

21. Houël, E.; Fleury, M.; Odonne, G.; Nardella, F.; Bourdy, G.; Vonthron-Sénécheau, C.; Villa, P.; Obrecht, A.; Eparvier, V.; Deharo, E.; et al. Antiplasmodial and anti-inflammatory effects of an antimalarial remedy from the Wayana Amerindians, French Guiana: Takamalaimë (Psidium acutangulum Mart. ex DC., Myrtaceae). J. Ethnopharmacol. 2015, 166, 279-285. [CrossRef]

22. Zhang, J.-H.; Chung, T.D.Y.; Oldenburg, K.R. A Simple Statistical Parameter for Use in Evaluation and Validation of High Throughput Screening Assays. J. Biomol. Screen. 1999, 4, 67-73. [CrossRef]

23. Pedroso, D.; Tellechea, A.; Moura, L.; Carvalho, I.F.; Duarte, J.; Carvalho, E.; Ferreira, L. Improved Survival, Vascular Differentiation and Wound Healing Potential of Stem Cells Co-Cultured with Endothelial Cells. PLoS ONE 2011, 6, e16114. [CrossRef] [PubMed]

24. Zhang, Y.; García-Gabilondo, M.; Grayston, A.; Feiner, I.V.J.; Anton-Sales, I.; Loiola, R.A.; Llop, J.; Ramos-Cabrer, P.; Barba, I.; Garcia-Dorado, D.; et al. PLGA protein nanocarriers with tailor-made fluorescence/MRI/PET imaging modalities. Nanoscale 2020, 12, 4988-5002. [CrossRef] [PubMed]

25. Nishihara, H.; Soldati, S.; Mossu, A.; Rosito, M.; Rudolph, H.; Muller, W.A.; Latorre, D.; Sallusto, F.; Sospedra, M.; Martin, R.; et al. Human CD4+ T cell subsets differ in their abilities to cross endothelial and epithelial brain barriers in vitro. Fluids Barriers CNS 2020, 17, 3-18. [CrossRef] [PubMed]

26. Viswanathan, G.K.; Shwartz, D.; Losev, Y.; Arad, E.; Shemesh, C.; Pichinuk, E.; Engel, H.; Raveh, A.; Jelinek, R.; Cooper, I.; et al. Purpurin modulates Tau-derived VQIVYK fibrillization and ameliorates Alzheimer's disease-like symptoms in animal model. Cell Mol. Life Sci 2019. [CrossRef] [PubMed]

27. Dehouck, M.-P.; Bree, F.; Fruchart, J.-C.; Cecchelli, R.; Tillement, J.-P.; Jolliet-Riant, P. Drug Transfer Across the Blood-Brain Barrier: Correlation Between In Vitro and In Vivo Models. J. Neurochem. 1992, 58, 1790-1797. [CrossRef]

28. Descat, A.; Lecoeur, M.; Kouach, M.; Goossens, L.; Thelliez, A.; Odou, P.; Decaudin, B.; Goossens, J.-F. Simultaneous determination of di(2-ethylhexyl) phthalate and diisononylcyclohexane-1,2-dicarboxylate and their monoester metabolites in four labile blood products by liquid chromatography tandem mass spectrometry. J. Pharm. Biomed. Anal. 2020, 181, 113063. [CrossRef]

29. Siflinger-Birnboim, A.; Del Vecchio, P.J.; Cooper, J.A.; Blumenstock, F.A.; Shepard, J.M.; Malik, A.B. Molecular sieving characteristics of the cultured endothelial monolayer. J. Cell. Physiol. 1987, 132, 111-117. [CrossRef]

30. Rispin, A.; Farrar, D.; Margosches, E.; Gupta, K.; Stitzel, K.; Carr, G.; Greene, M.; Meyer, W.; McCall, D. Alternative methods for the median lethal dose $(\operatorname{LD}(50))$ test: The up-and-down procedure for acute oral toxicity. ILAR J. 2002, 43, 233-243. [CrossRef] 
31. Organisation for Economic Co-Operation and Development. Guidance document on acute oral toxicity testing. In OECD Environment, Health and Safety Publications Series on Testing and Assessment $\mathrm{n}^{\circ} 24$, Paris, France. June 2001; 1-24.

32. Nervo, A.; Calas, A.-G.; Nachon, F.; Krejci, E. Respiratory failure triggered by cholinesterase inhibitors may involve activation of a reflex sensory pathway by acetylcholine spillover. Toxicology 2019, 424, 152232. [CrossRef]

33. Santoni, G.; De Sousa, J.; De La Mora, E.; Dias, J.; Jean, L.; Sussman, J.L.; Silman, I.; Renard, P.-Y.; Brown, R.C.D.; Weik, M.; et al. Structure-Based Optimization of Nonquaternary Reactivators of Acetylcholinesterase Inhibited by Organophosphorus Nerve Agents. J. Med. Chem. 2018, 61, 7630-7639. [CrossRef]

34. Gorecki, L.; Junova, L.; Kucera, T.; Hepnarova, V.; Prchal, L.; Kobrlova, T.; Múčková, L'; Soukup, O.; Korábečný, J. Tacroximes: Novel unique compounds for the recovery of organophosphorus-inhibited acetylcholinesterase. Futur. Med. Chem. 2019, 11, 2625-2634. [CrossRef] [PubMed]

35. Kobrlová, T.; Korábečný, J.; Soukup, O. Current approaches to enhancing oxime reactivator delivery into the brain. Toxicol. 2019, 423, 75-83. [CrossRef] [PubMed]

36. Sakurada, K.; Matsubara, K.; Shimizu, K.; Shiono, H.; Seto, Y.; Tsuge, K.; Yoshino, M.; Sakai, I.; Mukoyama, H.; Takatori, T. Pralidoxime Iodide (2-PAM) Penetrates Across the Blood-Brain Barrier. Neurochem. Res. 2003, 28, 1401-1407. [CrossRef] [PubMed]

37. Múčková, L'.; Pejchal, J.; Jošt, P.; Vanova, N.; Herman, D.; Jun, D. Cytotoxicity of acetylcholinesterase reactivators evaluated in vitro and its relation to their structure. Drug Chem. Toxicol. 2018, 42, 252-256. [CrossRef]

38. Blackard, W.G.; Sood, G.K.; Crowe, D.R.; Fallon, M.B. Tacrine. J. Clin. Gastroenterol. 1998, 26, 57-59. [CrossRef] [PubMed]

39. Patocka, J.; Jun, D.; Kuca, K. Possible role of hydroxylated metabolites of tacrine in drug toxicity and therapy of Alzheimer's disease. Curr. Drug Metab. 2008, 9, 332-335. [CrossRef] [PubMed]

40. Dos Santos, A.A.; Dos Santos, D.B.; Ribeiro, R.P.; Colle, D.; Peres, K.C.; Hermes, J.; Barbosa, A.M.; Dafre, A.L.; De Bem, A.F.; Kuca, K.; et al. Effects of K074 and pralidoxime on antioxidant and acetylcholinesterase response in malathion-poisoned mice. NeuroToxicology 2011, 32, 888-895. [CrossRef]

41. Žunec, S.; Radić, B.; Musilek, K.; Musilek, K.; Vrdoljak, A.L. Comparative determination of the efficacy of bispyridinium oximes in paraoxon poisoning / Usporedno određivanje učinkovitosti bispiridinijevih oksima pri trovanju paraoksonom. Arch. Ind. Hyg. Toxicol. 2015, 66, 129-134. [CrossRef]

42. Kovarik, Z.; Čalić, M.; Šinko, G.; Bosak, A.; Berend, S.; Vrdoljak, A.L.; Radić, B. Oximes: Reactivators of phosphorylated acetylcholinesterase and antidotes in therapy against tabun poisoning. Chem. Interactions 2008, 175, 173-179. [CrossRef]

43. Lallement, G.; Baille, V.; Baubichon, D.; Carpentier, P.; Collombet, J.-M.; Filliat, P.; Foquin, A.; Four, E.; Masqueliez, C.; Testylier, G.; et al. Review of the value of huperzine as pretreatment of organophosphate poisoning. NeuroToxicology 2002, 23, 1-5. [CrossRef]

(C) 2020 by the authors. Licensee MDPI, Basel, Switzerland. This article is an open access article distributed under the terms and conditions of the Creative Commons Attribution (CC BY) license (http://creativecommons.org/licenses/by/4.0/). 